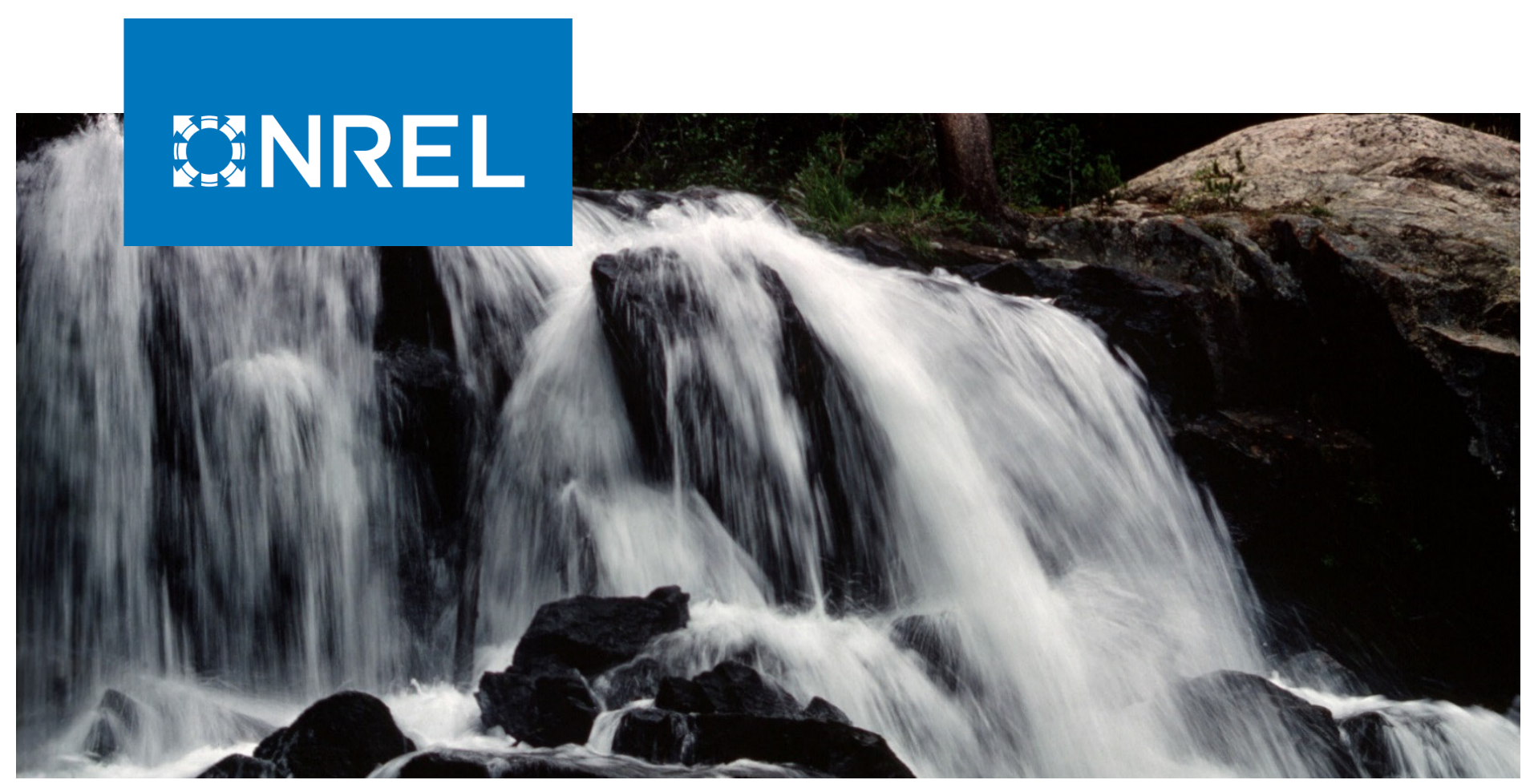

\title{
Barriers and Opportunities for U.S. Hydropower Industry Engagement in Brazil and Argentina
}

Karin Wadsack, ${ }^{1}$ Jennifer Daw, ${ }^{1}$ Omar Jose Guerra Fernandez, ${ }^{1}$ Donna Heimiller, ${ }^{1}$ Elise DeGeorge, ${ }^{1}$ Vickie Healey, ${ }^{1}$ Erol Chartan, ${ }^{1}$ and Josue Campos do Prado ${ }^{2}$

${ }^{1}$ National Renewable Energy Laboratory

${ }^{2}$ Washington State University

NREL is a national laboratory of the U.S. Department of Energy Office of Energy Efficiency \& Renewable Energy

Operated by the Alliance for Sustainable Energy, LLC

This report is available at no cost from the National Renewable Energy Laboratory (NREL) at www.nrel.gov/publications.
Technical Report

NREL/TP-6A65-78265

February 2021 


\section{GHREL}

\section{Barriers and Opportunities for U.S. Hydropower Industry Engagement in Brazil and Argentina}

Karin Wadsack, ${ }^{1}$ Jennifer Daw, ${ }^{1}$ Omar Jose Guerra Fernandez, ${ }^{1}$ Donna Heimiller, ${ }^{1}$ Elise DeGeorge,${ }^{1}$ Vickie Healey, ${ }^{1}$ Erol Chartan, ${ }^{1}$ and Josue Campos do Prado ${ }^{2}$

${ }^{1}$ National Renewable Energy Laboratory

${ }^{2}$ Washington State University

\section{Suggested Citation}

Wadsack, Karin, Jennifer Daw, Omar Jose Guerra Fernandez, Donna Heimiller, Elise DeGeorge, Vickie Healey, Erol Chartan, and Josue Campos do Prado. 2021. Barriers and Opportunities for U.S. Hydropower Industry Engagement in Brazil and Argentina. Golden, CO: National Renewable Energy Laboratory. NREL/TP-6A65-78265.

https://www.nrel.gov/docs/fy210sti/78265.pdf.

NREL is a national laboratory of the U.S. Department of Energy Office of Energy Efficiency \& Renewable Energy Operated by the Alliance for Sustainable Energy, LLC

This report is available at no cost from the National Renewable Energy Laboratory (NREL) at www.nrel.gov/publications.

Contract No. DE-AC36-08GO28308
Technical Report

NREL/TP-6A65-78265

February 2021

National Renewable Energy Laboratory 15013 Denver West Parkway Golden, CO 80401

303-275-3000 • www.nrel.gov 


\section{NOTICE}

This work was authored in part by the National Renewable Energy Laboratory, operated by Alliance for Sustainable Energy, LLC, for the U.S. Department of Energy (DOE) under Contract No. DE-AC36-08GO28308. Funding provided by U.S. Department of Energy Office of Energy Efficiency and Renewable Energy and managed by the Office of International Affairs. The views expressed herein do not necessarily represent the views of the DOE or the U.S. Government.

This report is available at no cost from the National Renewable Energy Laboratory (NREL) at www.nrel.gov/publications.

U.S. Department of Energy (DOE) reports produced after 1991 and a growing number of pre-1991 documents are available free via www.OSTI.gov.

Cover Photo by Jim Miller, NREL 03282

NREL prints on paper that contains recycled content. 


\section{Acknowledgments}

The National Renewable Energy Laboratory team recognizes and appreciates the support of Jay Applewhite and Raul Ferro, of Industry Exchange LLC. Applewhite and Ferro distributed the project survey to Latin American companies (shown in Appendix A) and completed the initial versions of the Latin American perspectives and electrical sector background. The team is also grateful for the support of Segrity, Inc. for sharing their experiences entering the Argentinian hydropower market as well as all of the industry partners who generously gave us their time and input during the interview process. In addition, members of the embassy and consulates in both Brazil and Argentina, Igly Serafim, Marcelo Amden, and Karen Ballard, respectively, provided invaluable insight along with Empresa de Pesquisa Energética (EPE) in Brazil. We especially want to thank our partners at the Department of Energy, including our sponsors in the Office of Energy Efficiency and Renewable Energy (EERE), and our project leads in the Office of International Affairs Elena Berger and Sandra Dickison, for their support of this important analysis of the hydropower sector in portions of Latin America. 


\section{List of Acronyms}

ANEEL

BNDES

CAMMESA

CDE

DEVI

DFC

EIA

ENRE

EPE

EU

GSF

GW

IEA

IEEE

IFC

IPP

$\mathrm{m}$

MW

NASA

NDCs

NREL

O\&M

PDE

PNE

PPA

PROINFA

PV

SEDAC

SIA

USGS

USTDA

VRE
Agência Nacional de Energia Elétrica, National Electric Energy Agency

(Brazil)

Brazilian National Development Bank

Compañía Administradora del Mercado Mayorista Eléctrico SA

(Argentina)

Energy Development Fund (Brazil)

Dam Environmental Vulnerability Index

U.S. International Development Finance Corporation

Environmental Impact Assessment

Ente Nacional Regulador de la Electricidad, National Regulatory

Commission for Electricity (Argentina)

Empresa de Pesquisa Energética, Energy Research Office (Brazil)

European Union

Generation Scaling Factor

gigawatt

International Energy Agency

Institute of Electrical and Electronic Engineers

International Finance Corporation

independent power producers

meters

megawatt

National Aeronautics and Space Administration

Nationally Determined Contributions

National Renewable Energy Laboratory

operation and maintenance

Energy Development Plan (Brazil)

Plano Nacional de Energia, National Energy Plan (Brazil)

power purchase agreement

Alternative Energy Source Incentive Program (Brazil)

photovoltaic

Socioeconomic Data and Applications Center

Social Impacts Assessment

U.S. Geological Survey

U.S. Trade and Development Agency

variable renewable energy 


\section{Table of Contents}

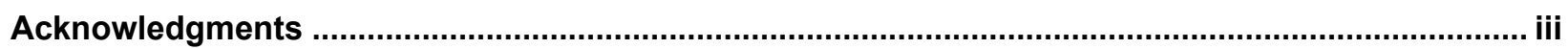

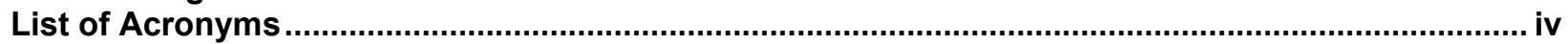

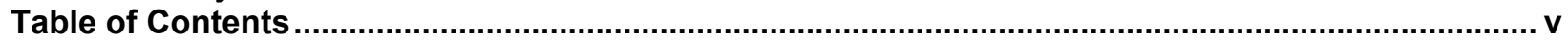

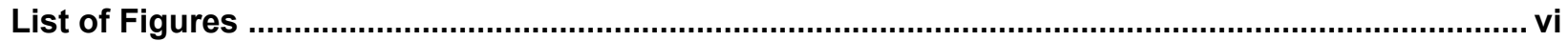

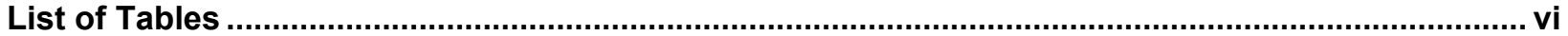

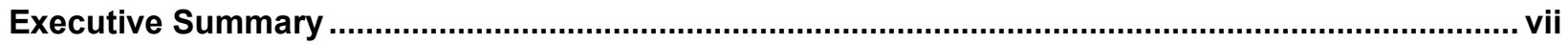

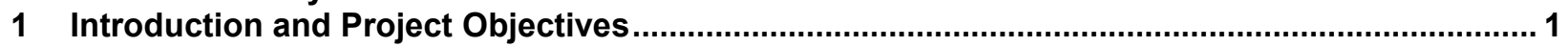

1.1 Key Drivers for Hydropower in Brazil and Argentina ...................................................... 2

2 Hydroelectric Resource and Infrastructure Data Set Summary .............................................. 3

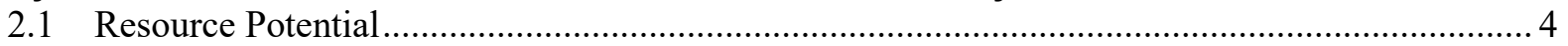

2.2 Geographic Characterization .................................................................................. 5

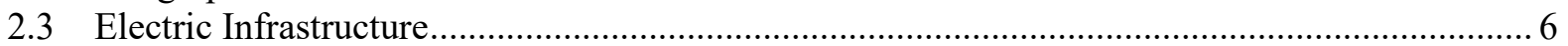

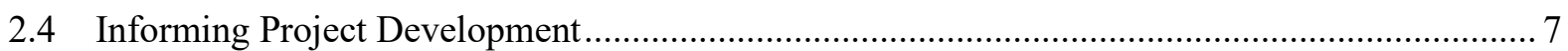

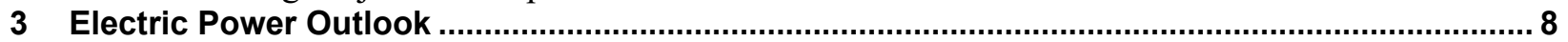

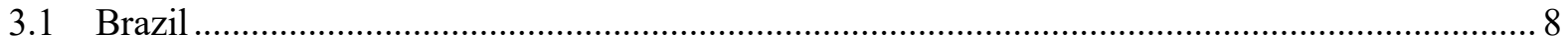

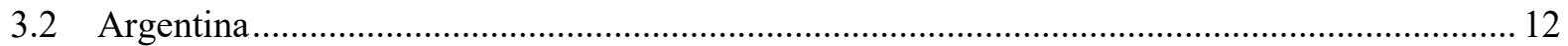

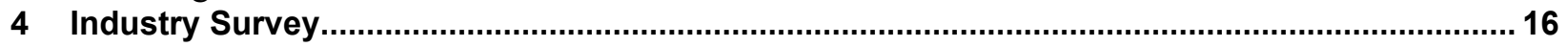

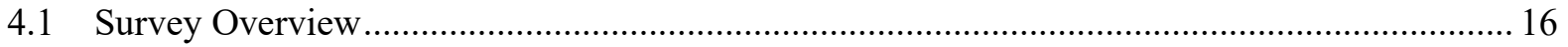

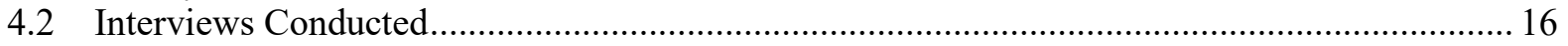

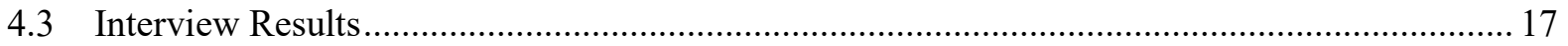

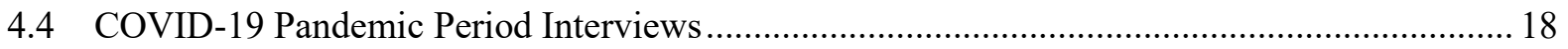

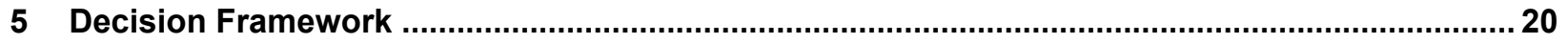

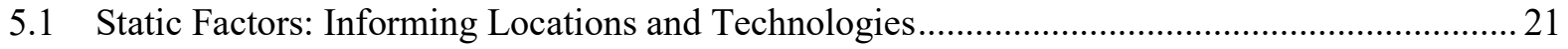

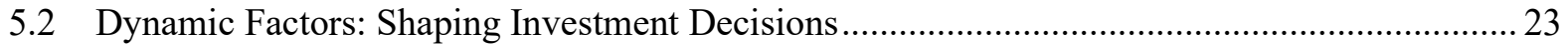

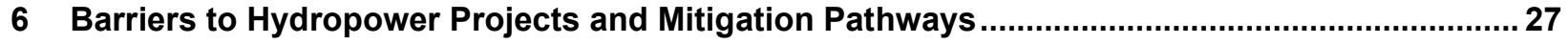

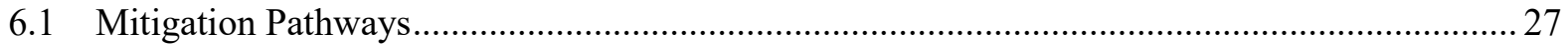

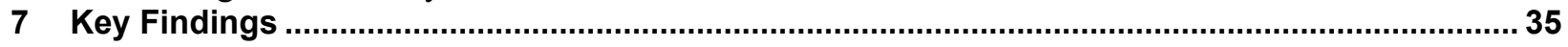

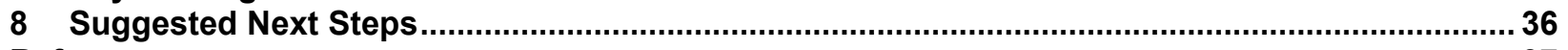

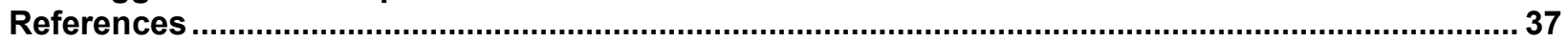

Appendix A. Latin America Survey Distributed Through Industry Exchange LLC ....................43

Appendix B. Interview Questions Used With U.S. Industry Representatives ............................46

Appendix C. Brazil and Argentina Background and Energy Landscape ......................................48

C.1 Electricity Market and Renewables Regulation in Brazil ....................................................... 48

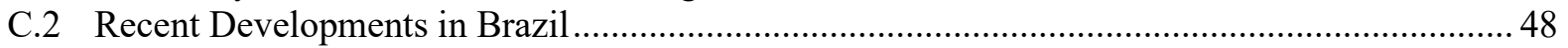

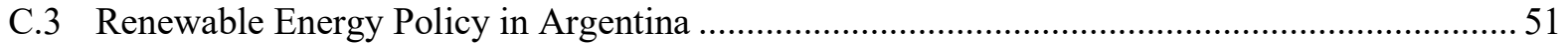

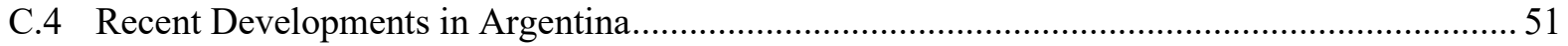




\section{List of Figures}

Figure ES-1. Steps in industry decision process regarding hydroelectric project development .... vii Figure ES-2. Brazil and Argentina hydroelectric and pumped storage potential............................ viii

Figure ES-3. Example question from Latin America industry survey (Have you invested or are you considering investing in energy projects in this country?) ......................................................... ix

Figure ES-4. Static and dynamic factors influencing industry development and investment

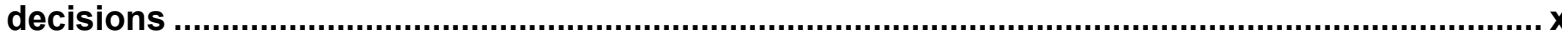

Figure ES-5. Summary of the project's initial Barriers Assessment and Mitigation Strategies Library.

Figure ES-6. Potential project next steps ..................................................................................... xi

Figure 1. Gross potential capacity for conventional hydropower ....................................................... 3

Figure 2. Gross potential sites with $5 \mathrm{GWh}$ ( $\sim 833 \mathrm{MW}$ with storage available for 6 hours) of pumped storage hydropower. The colors from darkest to lightest represent the most to least cost-effective development projects as ranked in the Australian National University's Global Pumped Hydro Atlas.

Figure 3. Brazil's electricity generating capacity (GW) by type, 1980-2018 (U.S. Energy Information

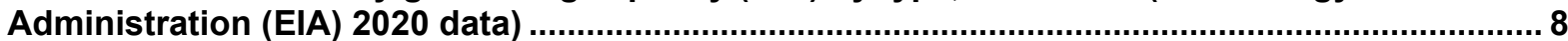

Figure 4. Argentine electricity generating capacity, 1980-2018 (EIA data) ..................................... 12

Figure 5. Summary of static and dynamic factors in decision framework ....................................20

\section{List of Tables}

Table 1. Geographic Characterization Data Sets and Sources ............................................................... 6

Table 2. EPE Expansion Already Under Contract as of 2019 (0 MW contracted in 2027-29) Data Source:

EPE 2029 Plan Executive Summary ................................................................................... 10

Table 3. Small-Hydro Projects Contracted through Argentina's RenovAr Auction Rounds 1, 2, and 3 ... 14

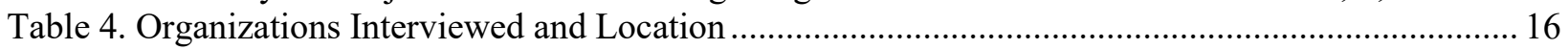

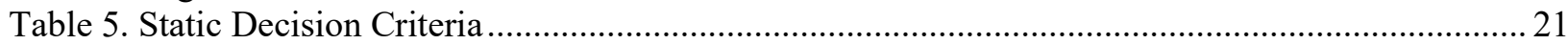

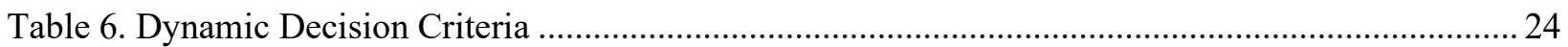

Table 7. Barriers to Hydropower Development in Brazil and Argentina ............................................... 27

Table 8. Key Findings from Each Project Element........................................................................... 35 


\section{Executive Summary}

This project, Barriers and Opportunities for U.S. Hydropower Industry Engagement in Brazil and Argentina, seeks to enhance the understanding of hydropower resources, existing installations, and opportunities for U.S. company involvement in hydropower development in Brazil and Argentina. This work was performed by the National Renewable Energy Laboratory (NREL) in collaboration with industry members and the U.S. Department of Energy Office of International Affairs. It covers conventional hydropower, pumped storage hydropower, run-ofriver hydropower, in-conduit generation, hydropower upgrades to existing facilities, and similar systems. This work seeks to support the decision process for U.S. industry engaged in hydropower development using the steps shown in Figure ES-1.

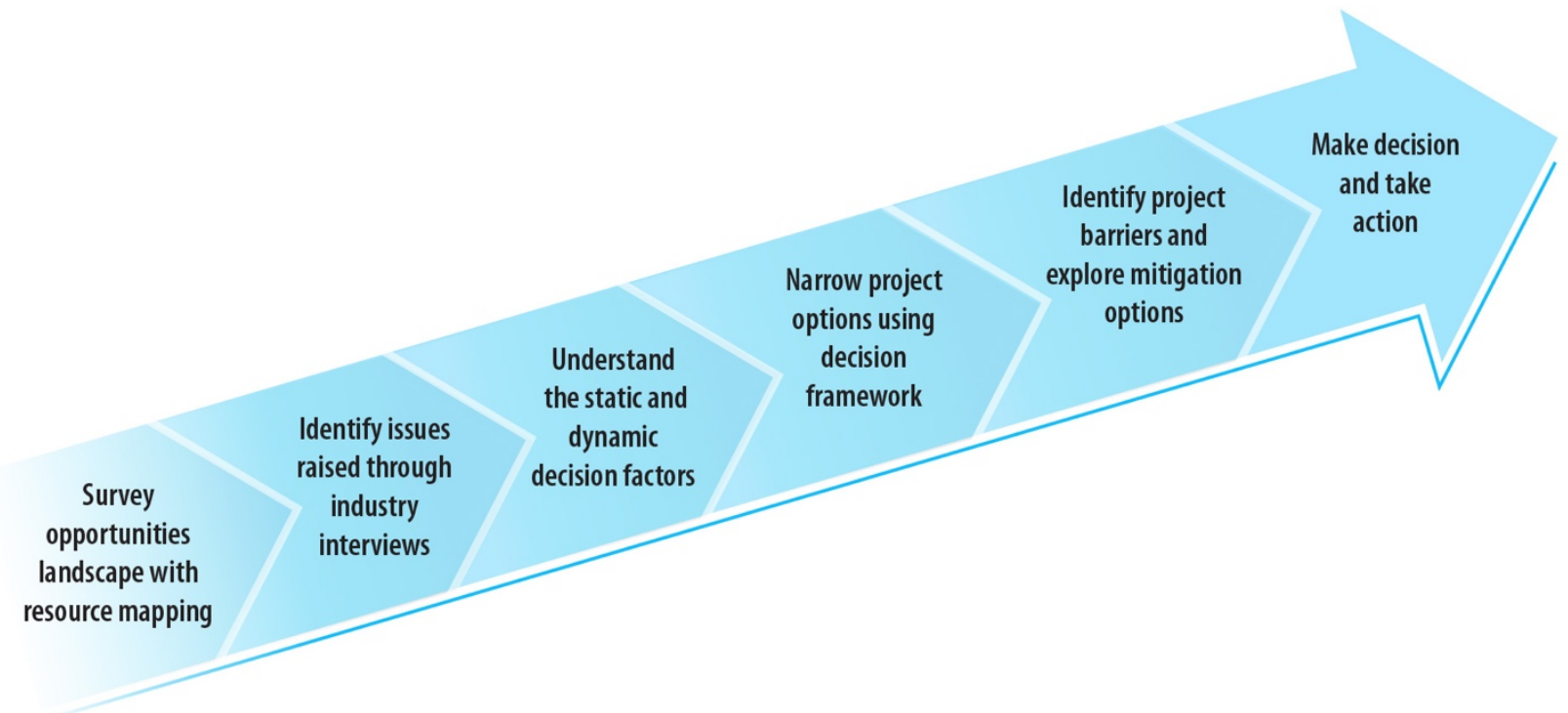

Figure ES-1. Steps in industry decision process regarding hydroelectric project development

The project gathered publicly available national data sets of hydropower resources and existing installations to establish an understanding of existing and planned infrastructure and key players who have been involved in these activities. Resources for hydropower and pumped storage (specifically showing locations that could yield 6 hours of storage and a total of $5 \mathrm{GWh}$ of capacity, color coded darkest to lightest from most to least economically viable, as ranked by Australian National University's Global Pumped Hydro Atlas) ${ }^{1}$ development are shown in Figure ES-2. Available data sets confirm that there is abundant technical potential for hydropower development at all scales and pumped hydroelectric project development in both Argentina and Brazil.

\footnotetext{
${ }^{1}$ Available at http://re100.eng.anu.edu.au/global/
} 


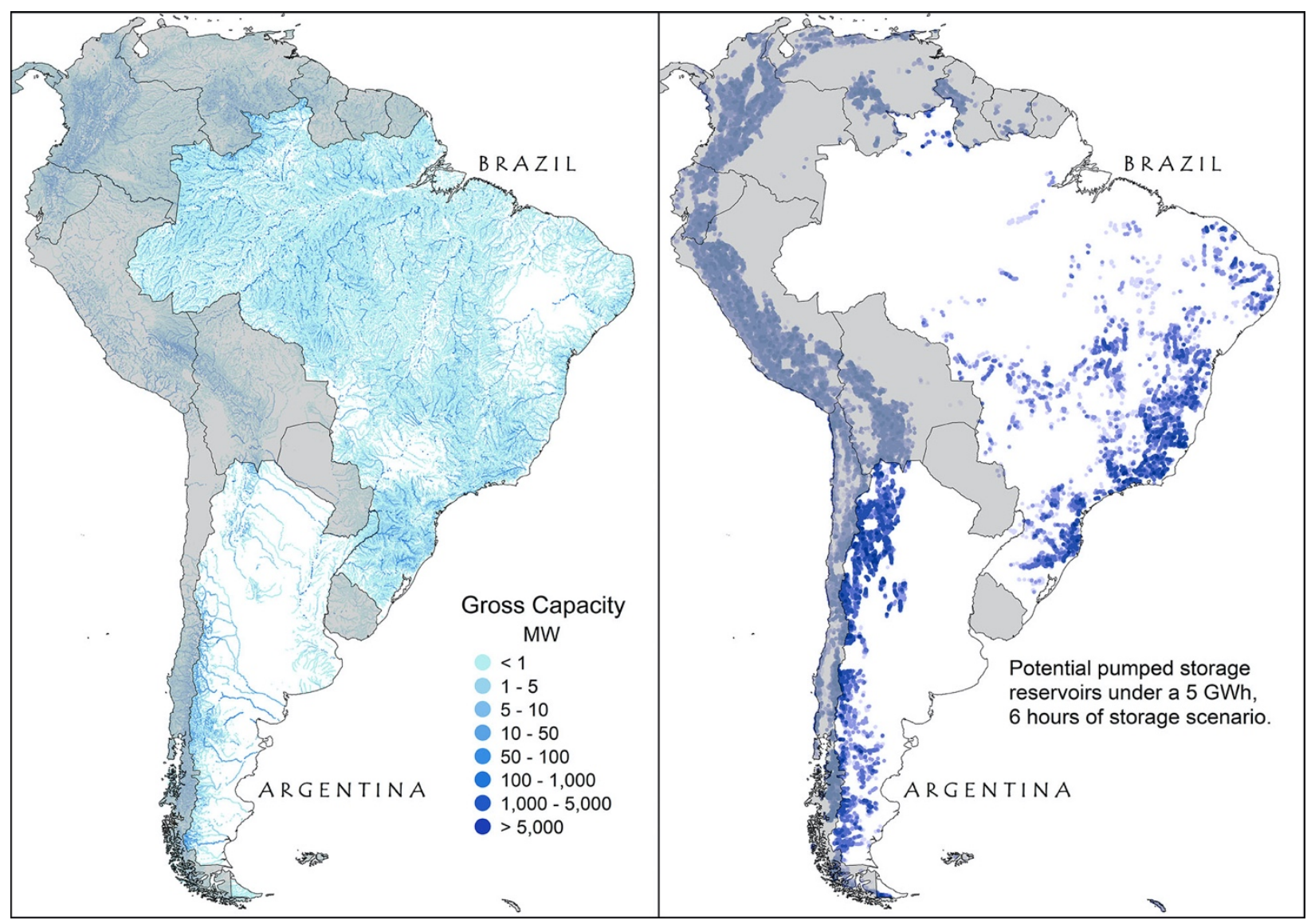

Figure ES-2. Brazil and Argentina hydroelectric and pumped storage potential

The project team evaluated country policies, economics, power system regulations and infrastructure, determining that these support limited development of hydropower projects, particularly where there is complementarity with variable generation and access to transmission infrastructure. Additional transmission buildout, advances in hydropower technology, decarbonization goals and electricity market reform will support further hydropower development. Economic instability due to COVID-19 and other domestic challenges, particularly in the case of Argentina, increase investment risk for U.S. and other foreign companies or financers.

To obtain more detailed information about hydropower development activities in these countries and improve understanding of any infrastructure, policy, regulatory, environmental, and economic barriers, the team then identified and interviewed ${ }^{2}$ U.S. hydropower developers, contractors, consultants, financiers, and other industry experts. Additionally, NREL engaged project partner Industry Exchange to survey Latin American companies to gather local and regional perspectives (A sample question from the survey is provided in Figure ES-3). Using this information, this project was able to incorporate a deeper understanding of how hydropower development in these countries can benefit U.S. industry and what barriers U.S. companies may face in the Latin America region. Responses indicated that the strongest development

\footnotetext{
${ }^{2}$ Interview questions are included in Appendices A and B.
} 
opportunities may be in smaller projects, run-of-river technologies, and retrofits to existing facilities in both countries, especially in the near term. The strength of domestic firms, particularly in Brazil, may limit U.S. company opportunities.

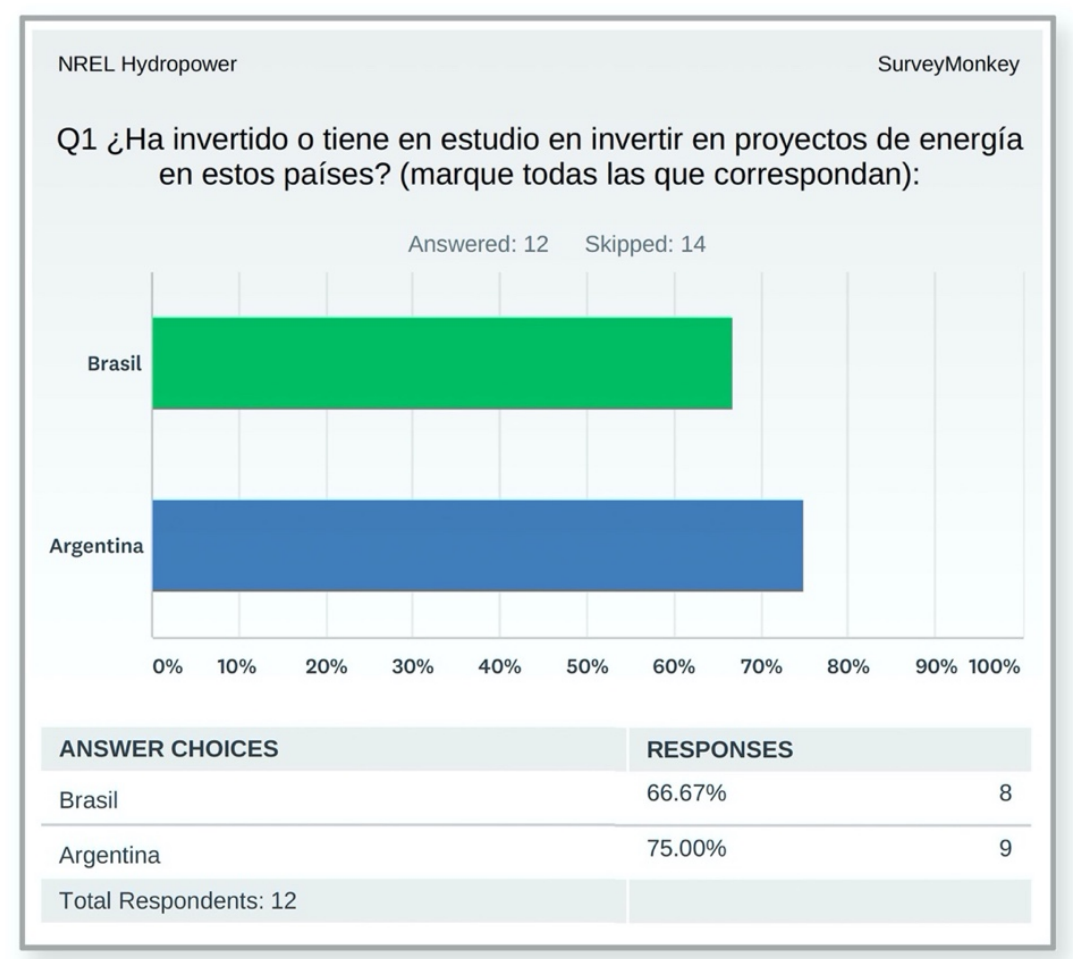

Figure ES-3. Example question from Latin America industry survey (Have you invested or are you considering investing in energy projects in this country?)

The case studies and recommendations gathered from industry experts in the United States, Brazil, and Argentina informed initial development of a decision framework and a library of mitigation strategies. Investment decisions are influenced by the region's environment, economic landscape, social constraints, policies, and technical or power system dynamics. These considerations can be categorized into static or dynamic factors. Developers should determine or consult the current status of this list of factors (Figure ES-4) to support their decision process. Certainly, all of these factors change over time; those listed as 'dynamic' are the most sensitive to potentially volatile outside influences. 

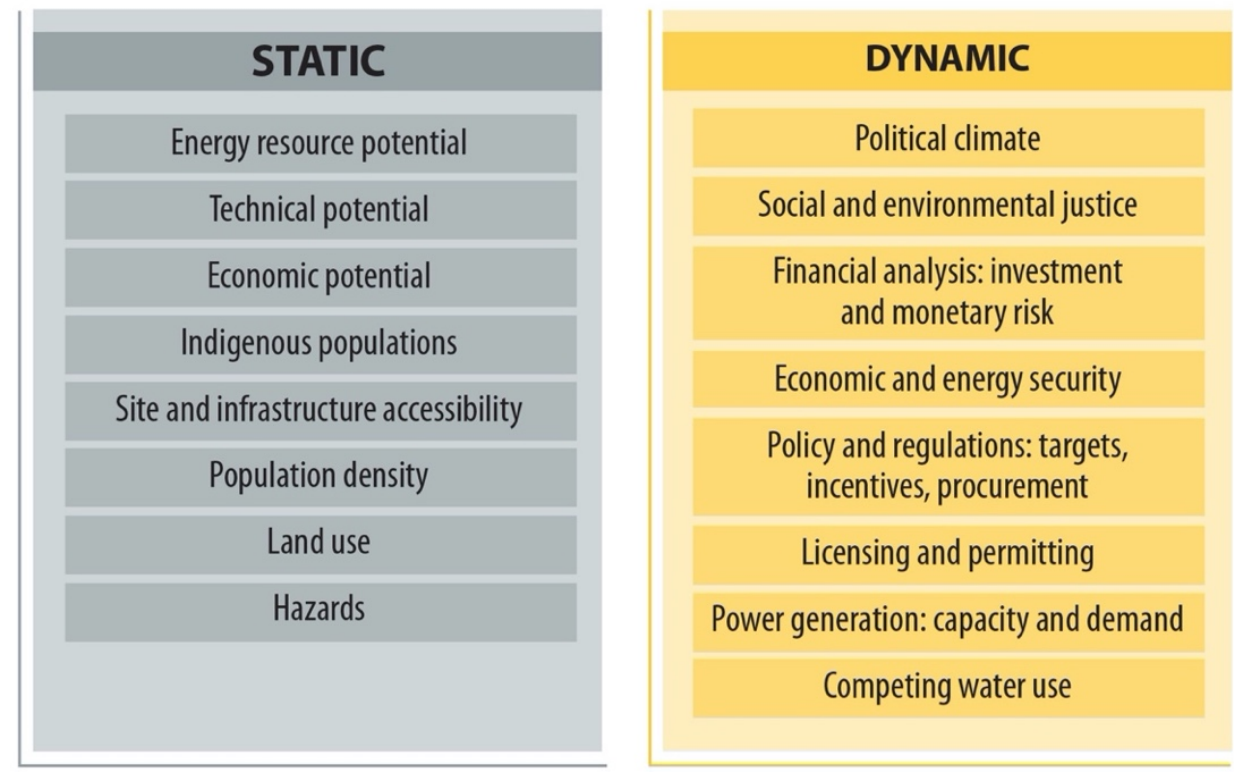

Figure ES-4. Static and dynamic factors influencing industry development and investment decisions

The goal of these resources is to support the decision processes of U.S. industry surrounding engagement in Brazil or Argentina, and to offer solutions to common project challenges based on decades of experience among industry professionals in each country and abroad, through a Mitigation Strategies Library (Figure ES-5). Some of these strategies are more significant than others. Project-level opposition and the positioning of a project with respect to the country's power system infrastructure constraints and market rules are critical considerations that merit deeper exploration by potential developers.
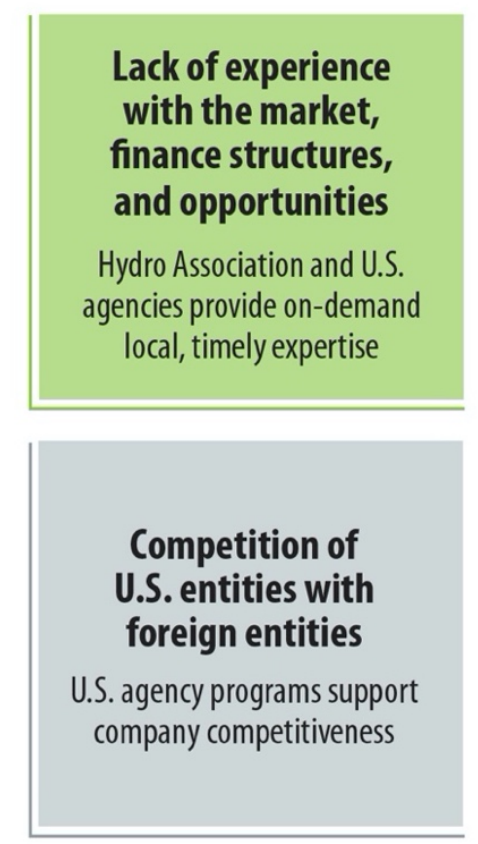
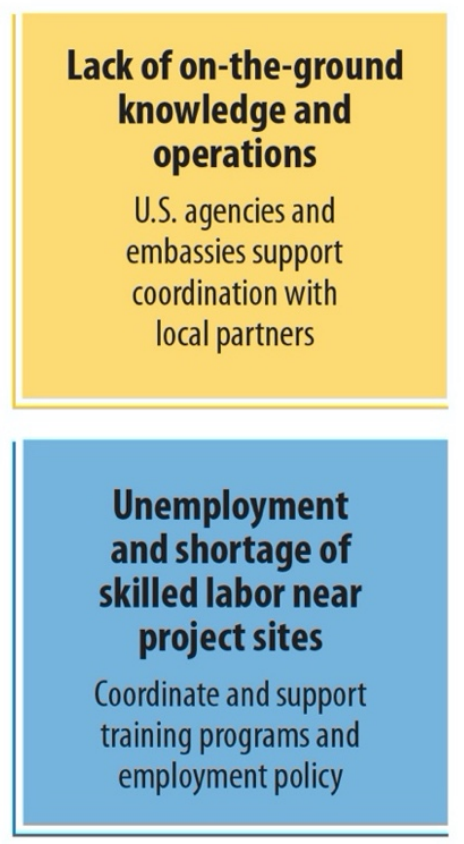
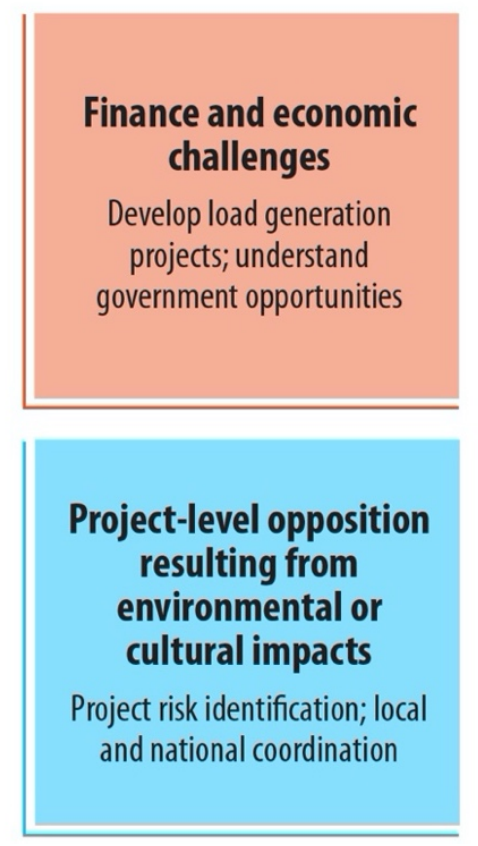

Figure ES-5. Summary of the project's initial Barriers Assessment and Mitigation Strategies Library 
These tools can be updated to adapt to changes in the industry landscape within each country over time and can also be adapted for use in other countries or regions of the world. This project can be expanded (Figure ES-6) to provide additional tools for industry that support hydroelectric project investment and development decisions in Brazil, Argentina, or across Latin America.

Disseminate project results

Deeper dive in Brazil and Argentina
Collaborations, public presentations, networks

Obtaining data and needed information

Highest potential in Latin America

Replicate in other countries

Advance development of decision framework

Advance development of mitigation strategies
Context details and strategy refinement

Figure ES-6. Potential project next steps 


\section{Introduction and Project Objectives}

This project, Barriers and Opportunities for U.S. Hydropower Industry Engagement in Brazil and Argentina, seeks to enhance the understanding of hydropower resources, existing installations, and opportunities for U.S. company involvement in hydropower development in Brazil and Argentina. It covers conventional hydropower, pumped storage hydropower, run-ofriver hydropower, in-conduit generation, hydropower upgrades to existing facilities, and similar systems. This work recognizes that each of these countries, and even regions within the countries, have varied topography, weather, existing grid infrastructure, social, economic, and other factors, leading to relatively unique opportunities and challenges for hydropower development.

The initial investigation included examining publicly available national data sets of hydropower resources and existing installations to establish an understanding of existing and planned infrastructure and key players who have been involved in these activities. The team then identified and interviewed ${ }^{3}$ U.S. hydropower developers, contractors, consultants, financiers, and other industry experts to obtain more detailed information about hydropower development activities in these countries to improve understanding of any infrastructure, policy, regulatory, environmental, and economic barriers. Additionally, the National Renewable Energy Laboratory (NREL) engaged project partner Industry Exchange to survey Latin American companies to gather local and regional perspectives. Using this information, this project provides a deeper understanding of how hydropower development in these countries can benefit U.S. industry and what barriers U.S. companies may face in the Latin America region.

The project team used the case studies and recommendations gathered from industry experts in the United States, Brazil, and Argentina to inform the initial development of two resources: a decision framework and a library of mitigation strategies. Each resource is presented in this report in its first development phase, with examples and a layout of future potential tool expansion. The goal of these resources is to support the decision processes of U.S. industry surrounding engagement in Brazil or Argentina, and to offer solutions to common project challenges based on decades of experience among industry professionals in each country and abroad. These tools can be updated to adapt to changes in the industry landscape within each country over time and can also be adapted for use in other countries or regions of the world.

This report was developed prior to and during the COVID-19 pandemic - an unprecedented tragedy affecting more than 188 countries worldwide. The pandemic has not only led to death and disruption, it has devastated global economies and impacted many sectors, including energy. As a result of pandemic shutdowns, many countries are in financial crisis and are experiencing workforce restrictions and reduced energy demand. These impacts have changed the need for, and ability to develop, new energy projects. While the emphasis of this report is not COVID-19, the sections below include descriptions of COVID-specific effects to shed light on the additional challenges being faced in the near and long term as a consequence of the pandemic.

\footnotetext{
${ }^{3}$ Interview questions are included in Appendices A and B.
} 


\subsection{Key Drivers for Hydropower in Brazil and Argentina}

Expected population and economic growth and a global trend toward increased use of renewable energy sources are key drivers of hydroelectric development. Hydroelectric power generation has been a strong global source of renewable electricity; this is particularly true in Brazil and Argentina, where hydropower has historically been a significant part of the energy matrix. As the power systems in each country evolve, the role of hydropower and the types, sizes, and locations of desired new hydropower facilities are also changing. Decarbonization goals in each country and across the continent may spur additional technology developments that support innovative hydroelectric and pumped storage projects and may change market dynamics such that projects that can offer multiple services to the power system can capture much greater economic value than they can today.

Hydropower generation can play a pivotal role in enabling the integration of much higher levels of variable renewable energy (VRE) sources (i.e., wind and solar photovoltaic (PV) power) in Brazil and Argentina. For instance, hydropower plants can enhance the flexibility of the Brazilian power systems across different timescales, which is required for the integration of VRE (Campos do Prado et al. 2019). Additionally, the seasonal complementarity of hydropower and VRE sources could facilitate the deployment of larger shares of wind and solar PV power in the Brazilian power grid (Cantão et al. 2017; Silva et al. 2016; Beluco et al. 2008). This complementarity reduces the need for other sources of power system flexibility, such as the deployment of energy storage capacity. 


\section{Hydroelectric Resource and Infrastructure Data Set Summary}

Hydropower generation data collection for Brazil and Argentina focused on publicly available data sets in geospatial formats, which are from primarily global sources. The data can be grouped into four major categories: resource potential (conventional hydropower and pumped storage hydropower); geographic characteristics; electric infrastructure; and potential barriers/market factors that might inform project development.

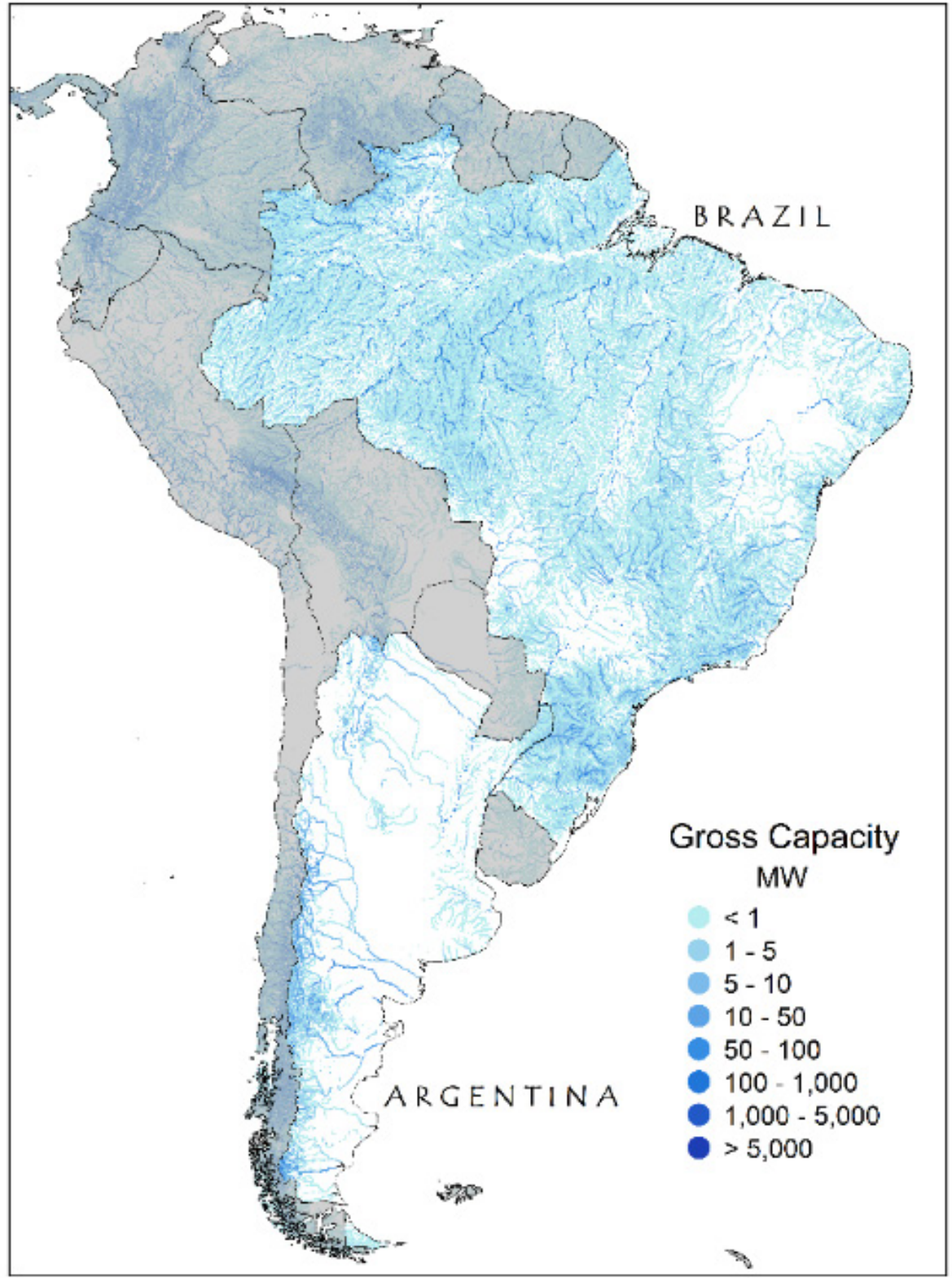

Figure 1. Gross potential capacity for conventional hydropower 


\subsection{Resource Potential}

Global resource data sets are available for conventional hydropower and pumped storage hydropower that can be used to characterize national patterns in resource potential for both Brazil and Argentina. NREL used these data to develop gross potential resource maps for both countries. The areas identified would require additional analysis and characterization before any project development could occur.

\subsubsection{Conventional Hydropower}

Estimates are available by country for gross and technical potential for conventional hydropower systems (Hoes et al. 2017). Estimates are generated at a resolution of 7.5 arc seconds (nominally $\sim 225 \mathrm{~m}$ ), and gross potential estimates are provided online at that resolution in a geospatial data format. Figure 1 created by NREL with this data, displays the conventional hydropower resource data for Brazil and Argentina.

\subsubsection{Pumped Storage Hydropower}

The Australian Global Pumped Hydro Atlas project (Stocks et al. 2019) provides estimates by country of potential closed-loop pumped storage hydropower, modeling artificial reservoir creation at different storage scales. Pumped storage projects may prove more economically viable as power markets evolve to better remunerate different services that these technologies can offer to the electrical system. Data was modeled using 30-m resolution elevation data. Modeled reservoir boundaries can be viewed in an interactive atlas, ${ }^{4}$ and spreadsheets with reservoir centroid locations are publicly available for download as well. Figure 2, also created by NREL using this publicly available data, displays the potential pumped storage hydropower resource for Brazil and Argentina for one of the modeled scenarios.

\footnotetext{
${ }^{4}$ Available at https://nationalmap.gov.au/renewables/\#share=s-oDPMo1jDBBtwBNhD
} 


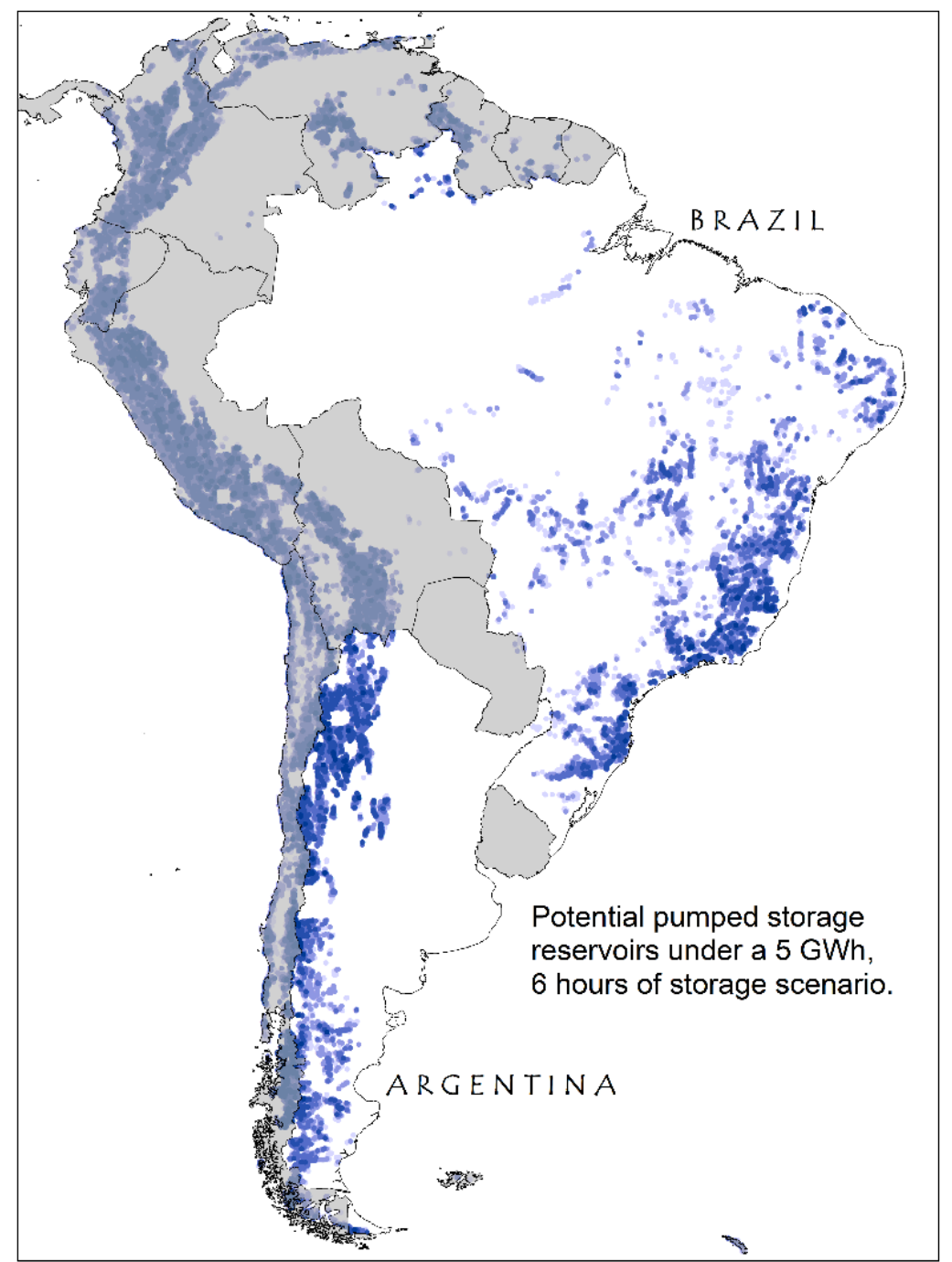

Figure 2. Gross potential sites with $5 \mathrm{GWh}$ ( $\sim 833 \mathrm{MW}$ with storage available for 6 hours) of pumped storage hydropower. The colors from darkest to lightest represent the most to least costeffective development projects as ranked in the Australian National University's Global Pumped Hydro Atlas. ${ }^{5}$

\subsection{Geographic Characterization}

This category includes base geospatial data sets, such as digital elevation models, hydrography, administrative boundaries, land cover, populated areas, and soil characteristics. These data could be used to build further map layers useful for identifying project development constraints. Table 1 provides a summary of available global data sets. These data could also include maps of locations of indigenous communities (see discussion in Section 5.1).

${ }^{5}$ Available at http://re100.eng.anu.edu.au/global/ 
Table 1. Geographic Characterization Data Sets and Sources

\begin{tabular}{|c|c|c|c|}
\hline Data Set & Description & Scale/Resolution & Source \\
\hline Elevation & $\begin{array}{l}\text { Gridded digital } \\
\text { elevation model, } \\
\text { elevation in meters }\end{array}$ & $\begin{array}{c}\text { Multiple; } \\
\text { highest is } 30 \mathrm{~m}\end{array}$ & $\begin{array}{l}\text { U.S. Geological Survey, Shuttle } \\
\text { Radar Topography Mission }\end{array}$ \\
\hline Hydrography & $\begin{array}{l}\text { Lakes, rivers, } \\
\text { streams }\end{array}$ & $10 \mathrm{~m}$ & $\begin{array}{c}\text { Natural Earth Data: } \\
\frac{\text { https://www.naturalearthdata.com/do }}{\text { wnloads/10m-physical-vectors/ }}\end{array}$ \\
\hline $\begin{array}{l}\text { Political } \\
\text { Boundaries }\end{array}$ & $\begin{array}{l}\text { County and internal } \\
\text { political boundaries }\end{array}$ & $10 \mathrm{~m}$ & $\begin{array}{c}\text { Natural Earth Data: } \\
\frac{\text { https://www.naturalearthdata.com/do }}{\text { wnloads/10m-physical-vectors/ }}\end{array}$ \\
\hline Cities/Towns & Populated areas & $10 \mathrm{~m}$ & $\begin{array}{c}\text { Natural Earth Data: } \\
\frac{\text { https://www.naturalearthdata.com/do }}{\text { wnloads/10m-physical-vectors/ }}\end{array}$ \\
\hline Land Cover & $\begin{array}{c}\text { Primary } \\
\text { classification of } \\
\text { land cover type } \\
\text { (forest, agriculture, } \\
\text { urban, etc.) } \\
\end{array}$ & $300 \mathrm{~m}$ & $\begin{array}{c}\text { GlobCover (2009): } \\
\frac{\text { https://databasin.org/datasets/693f57 }}{\underline{\text { 3b98834d1cbcc364e7f0b8e5db }}}\end{array}$ \\
\hline Soil Type & Global soil classes & $1 \mathrm{~km}$ & $\begin{array}{l}\text { Integrated Climate Data Center, } \\
\text { Harmonized World Soil Database. } \\
\text { http://www.fao.org/soils-portal/soil- } \\
\underline{\text { survey/soil-maps-and- }} \\
\frac{\text { databases/harmonized-world-soil- }}{\text { database-v12/en/ }}\end{array}$ \\
\hline
\end{tabular}

\subsection{Electric Infrastructure}

Global resource data sets are somewhat limited for electrical infrastructure; nevertheless, the available information could be mapped to further inform the project development decision process. An up-to-date global data set of existing power plant locations, with some plant characteristics, is available from the World Resources Institute. ${ }^{6}$ At the country level, data for Brazil appear to be readily available through the Agência Nacional de Energia Elétrica (ANEEL). ${ }^{7}$ These data sets include existing transmission lines and power plants separated by technology. A second web map ${ }^{8}$ displays similar information but does not make it available for download.

${ }^{6}$ Available at http://datasets.wri.org/dataset/globalpowerplantdatabase

${ }^{7}$ Available at https://sigel.aneel.gov.br/portal/home/

${ }^{8}$ Available at https://gisepeprd.epe.gov.br/webmapepe/ 
An interactive web map with similar electrical infrastructure data exists for Argentina, ${ }^{9}$ but the geospatial data does not appear to be downloadable publicly. Additional data sets with electrical infrastructure information are available through the Argentine government. ${ }^{10}$

\subsection{Informing Project Development}

Existing geospatial data layers can be identified, and new data sets developed, to help address key considerations that inform project development decisions, such as site and technology selection. Further discussion of how geospatial data can be used to assess hydropower and pumped hydro project opportunities in Latin America is included in Section 5.

${ }^{9}$ Available at https://sig.se.gob.ar/visor/visorsig.php

${ }^{10}$ Available at https://datos.gob.ar/ 


\section{Electric Power Outlook}

This document section summarizes the electric power outlook in Brazil and Argentina, including basic information on the social, policy, and economic landscapes, and the near-term opportunities for hydroelectric project development at all scales. An NREL project partner ${ }^{11}$ was leveraged to develop an overview of the power outlook for Brazil and Argentina in late 2019. The project team updated this information in mid-2020 to incorporate more recent plans and reports and to reflect recent developments and changes due to the COVID-19 pandemic. Each country section below concludes with a summary of the hydropower development opportunities for U.S. companies. Additional details on the electricity market, regulation, current project status, and recent developments are included in Appendix C.

\subsection{Brazil}

\subsubsection{Overview}

Historically, Brazil has had a very strong hydroelectric sector (Figure 3), meeting as much as three-quarters of the country's electricity demand (International Hydropower Association 2018). Large increases in installed capacity in 2018 and 2019, including the completion of the 11,233MW Belo Monte facility, made Brazil the second largest hydropower country in the world as measured by installed capacity, surpassing the United States and behind China (International Hydropower Association 2020a).

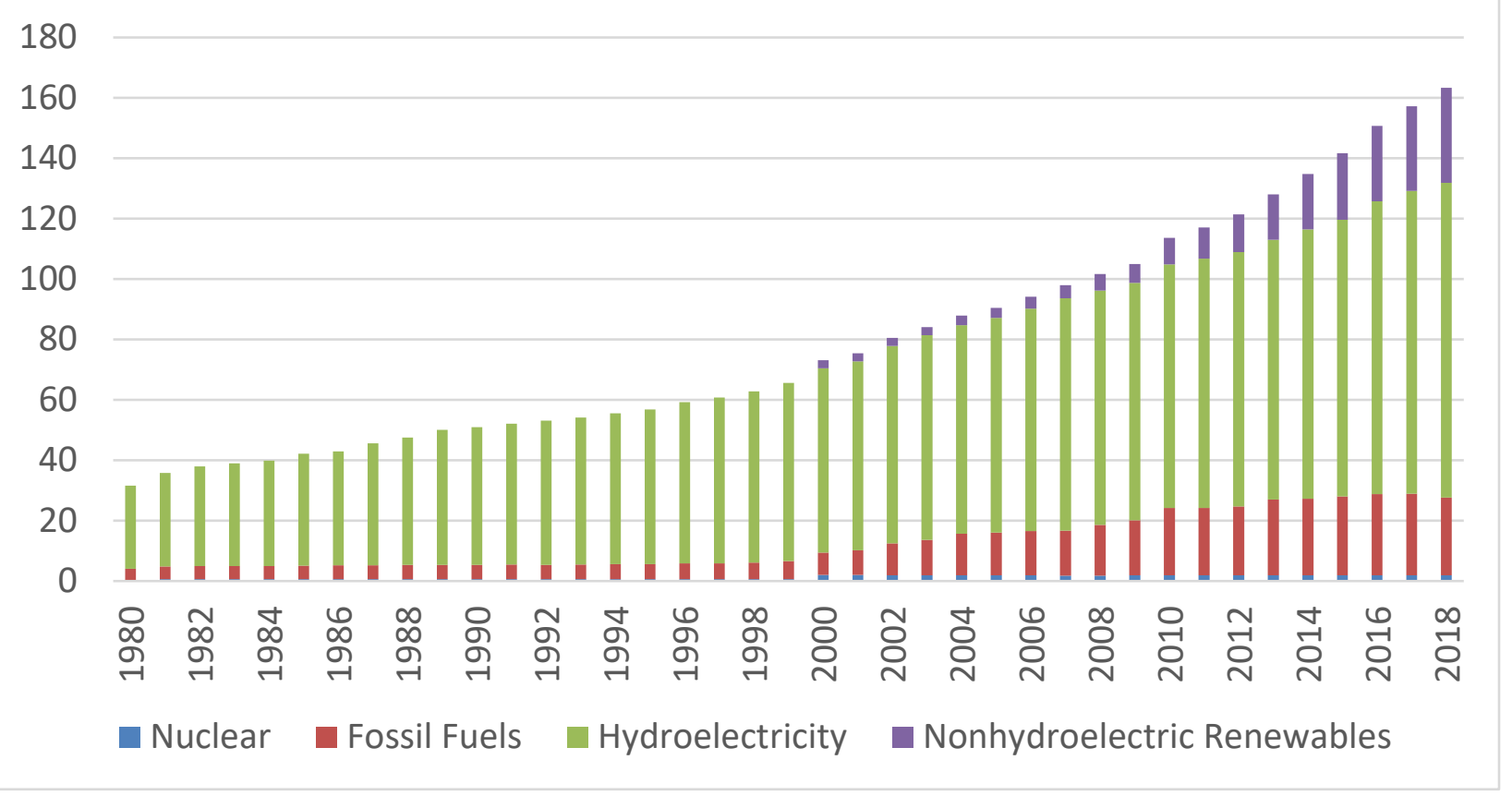

Figure 3. Brazil's electricity generating capacity (GW) by type, 1980-2018 (U.S. Energy Information Administration (EIA) 2020 data)

${ }^{11}$ Applewhite and Ferro, Industry Exchange, LLC. 
Brazil has the largest electric power market in Latin America. The energy sector has been under transformation the past 25 years, opening the electric power business to private and foreign investment and developing a more competitive market for generators. Power sector and market reform continues today.

A number of laws and regulations approved in the late 1990s fundamentally reconfigured the electricity market, requiring a public bidding process for all major energy concessions and energy contracts (International Renewable Energy Agency 2015). This developed an open energy market in which outside of the companies that have concessions to deliver power to geographically defined areas, larger power consumers were authorized to purchase energy through contracts or on an open market directly from electricity suppliers. To regulate and supervise this system, the government created the National Electric Energy Agency (ANEEL) and incorporated a wholesale market.

Three different types of legal entities can generate power for sale:

- Companies with public service concessions

- Independent power producers (IPPs) that receive a concession or authorization to generate power for sale

- Self-producers that obtain a concession or authorization to generate power exclusively for their own use.

Under certain regulatory circumstances, IPPs may also use the electricity generated, and selfproducers may sometimes sell excess electricity they produce to qualified third parties.

Currently, the power sector is comprised of two markets:

There is a regulated power market, composed mainly of distribution companies and the consumers in their concessions. The company-consumer relationship is regulated by ANEEL. The distribution companies are authorized to charge a determined rate (tariff) for electricity. They are required to procure all of their power supply through ANEEL-regulated auctions.

There is an open power market, composed of trading companies, power generators, and specific (larger-load) power consumers. These companies must have a minimum demand for electricity (currently, $2 \mathrm{MW}$, but with a demand threshold that is expected to be reduced further in 2021) and are free to negotiate their own power volumes and prices. Additional reforms are currently being considered by the Brazilian Congress. (More information about Brazil's electricity market regulations, recent developments, and COVID-19's effects on the hydropower sector in Brazil are included in Appendix C).

In the last few decades, changes in rainfall patterns and limited transmission capacity have resulted in the construction of fewer large-scale hydroelectric projects and more gas-fired thermoelectric plants. Additionally, social and environmental opposition to large dams in the Amazon region, which holds nearly half of the country's untapped hydroelectric power capacity, halted the development of new large hydropower projects. As mentioned above, the last one (the 11.2-GW Belo Monte plant) entered into full operation in 2019. 
In the mid-2019 Energy Development Plan (PDE) 2029 planning document (Brasil Ministerio de Minas e Energia 2019), the Brazilian Empresa de Pesquisa Energética (EPE, Energy Research Office) documented 1,400 MW of already-contracted hydropower (Table 2, summing hydroelectric, mini, and micro-hydro from 2020 through 2024). The plan also projected additional new development of nearly 4,000 MW of hydropower through 2029; much of the development potential was at the micro ( $<1 \mathrm{MW})$ and small (5-30 MW) scale, which would typically utilize run-of-river configurations. EPE also projected that up to 2,000 MW of capacity could be obtained through modernization upgrades to existing hydropower plants over the course of the coming decade.

In mid-2020, EPE released new documents describing its PDE 2030 projections, documenting a more limited projected increase in large- and small-scale hydroelectric plants (less than $1 \mathrm{GW}$, collectively) through 2030 (Brasil Ministerio de Minas e Energia 2020a). EPE's PDE 2030 revised peak load projections for 2029 down by $10 \mathrm{GW}$ from the projected load included in the PDE 2029 document in anticipation of reduced economic growth due to the effects of the COVID-19 pandemic (Brasil Ministerio de Minas e Energia 2020a, 2020b).

Table 2. EPE Expansion Already Under Contract as of 2019 (0 MW contracted in 2027-2029) Data Source: EPE 2029 Plan Executive Summary

\begin{tabular}{lrrrrrrr}
\hline \multicolumn{7}{c}{ Annual Increase (MW) } \\
\hline Sources & $\mathbf{2 0 2 0}$ & $\mathbf{2 0 2 1}$ & $\mathbf{2 0 2 2}$ & $\mathbf{2 0 2 3}$ & $\mathbf{2 0 2 4}$ & $\mathbf{2 0 2 5}$ & $\mathbf{2 0 2 6}$ \\
\hline Biomass + biogas & 231 & 147 & 50 & 115 & 0 & 0 & 0 \\
Wind power & 353 & 107 & 264 & 1,521 & 1,212 & 0 & 0 \\
Hydroelectric power & 611 & 36 & 0 & 204 & 0 & 0 & 0 \\
$\begin{array}{l}\text { SHPP + MHPP } \\
\text { (mini- and micro- }\end{array}$ & 225 & 177 & 111 & 10 & 38 & 0 & 0 \\
hydroelectric power) & & & & & & & \\
Photovoltaic power & 298 & 557 & 585 & 0 & 0 & 0 & 0 \\
Thermal power & 1,802 & 1,305 & 0 & 2,238 & 363 & 0 & 1,405 \\
\hline
\end{tabular}

Distributed generation capacity was also expected to grow over the next decade. The incentive to develop distributed generation projects depends in part on changes in the way that interconnection/transmission tariffs are allocated and energy is compensated; recent policy changes affecting compensation for on-site generation could reduce the amount of distributed generation development after these rule changes take effect in 2021 and 2022 (Brasil Ministerio de Minas e Energia 2019).

The National Energy Plan (PNE) for 2050 highlights the importance of existing and future hydroelectric plants in maintaining and increasing the renewable energy percentage of Brazil's energy matrix (Brasil Ministerio de Minas e Energia 2020c). The PNE documented $108 \mathrm{GW}$ of hydroelectric generating capacity in operation at the end of 2019 and $68 \mathrm{GW}$ of inventoried hydroelectric potential, including $52 \mathrm{GW}$ of large-scale and $16 \mathrm{GW}$ of small-capacity ( $<30 \mathrm{MW})$ projects. The majority of large project potential was documented in the Amazon and TocantinsAraguaia hydrographic regions, while smaller project potential was more geographically distributed throughout the country. Other development potential highlighted in the PNE included 
about $50 \mathrm{GW}$ of upgrade and modernization projects, which would be designed not only to increase power generation capacity but also to increase plant operational flexibility and utility as a tool for balancing the broader power system.

While the PNE 2050 planning document identified significant additional large and small hydropower development potential, the report cautioned that a number of factors would influence the viability of the identified resources and sites:

- Socioeconomic complexity of project development or expansion in indigenous territories and protected natural areas

- Economics of small hydroelectric projects

- International grid integration efforts and import or export of energy from Bolivia, Peru, Paraguay, and Argentina - all of which have significant hydroelectric development potential of their own

- Effects of climate change, which are expected to make the Northwestern Brazil projects less productive and consequently less cost-effective and economically competitive

- Changing value of hydroelectric resources with the evolution of power system management and infrastructure expansion, which should make hydropower more valuable as a grid management and variable renewable energy integration tool

- Other water and waterway use priorities (such as irrigation and shipping), which can affect, or be affected by, the development of hydroelectric facilities.

\subsubsection{Recent Developments}

As is the case worldwide, the Brazilian economy has been seriously affected by the COVID-19 pandemic. Reduced electricity demand and economic uncertainty create a less favorable situation for the development of all energy projects, including hydropower. Nevertheless, the Brazilian government is proceeding with planned electricity market reforms that may open new markets and improve the value proposition for hydroelectric power plants. Further details are included in Appendix C.

\subsubsection{Opportunities Summary}

Brazil's changing electricity market rules offer greater opportunities for hydroelectric project developers, including U.S. companies, to compete, particularly with smaller-scale, distributed projects in the under-5-MW range. Of course, the opportunities are in line with the economic performance of individual companies; opportunities should be considered in comparison to other companies or sectors in Latin America to assess viability. Reports published by EPE and the Brazilian Ministry of Mines and Energy suggest that these scales of projects will be favored over the next decade in order to support the development of generation where it is needed to meet local load growth. Further, these smaller projects may be viable in more geographic areas, if they can be constructed with a lower environmental impact (e.g., run of river configurations) and can effectively leverage variability in precipitation and stream flows. While there may be more opportunities at smaller scales, because margins on projects are likely to be smaller, it is 
incumbent upon U.S. companies to perform due diligence before embarking on development. Additionally, local partnerships may be even more important for identifying and competing for these opportunities. Projects at all scales will need to work with indigenous communities to mitigate conflict and gain community support. Opportunities for development at larger scales are likely to involve partnerships with Brazilian companies. There will also likely be ongoing opportunities in upgrading or retrofitting existing facilities. Because energy demand has been reduced due to COVID-19, project developers may want to keep a close eye on the socioeconomic situation in Brazil, consulting the factors detailed in Section 5, below, to inform any development decisions.

\subsection{Argentina}

\subsubsection{Hydropower Projects}

Argentina's recent energy policy and economic landscape are summarized here, with a detailed update specific to current circumstances provided in the Recent Developments and COVID-19 sections in Appendix C. Until the pandemic crisis and economic challenges, Argentina was recognized in recent years as offering strong opportunities for international investment in renewable energy projects.

The Argentine electric matrix is primarily made up of thermal power plants (Figure 4). Half of the capacity corresponds to natural gas generators, $30 \%$ to hydroelectricity, $11 \%$ to oil and diesel plants, $2.5 \%$ to renewables, and slightly more than $4 \%$ to nuclear energy. The market is fully open to the private sector, including regulated services (transmission and distribution).

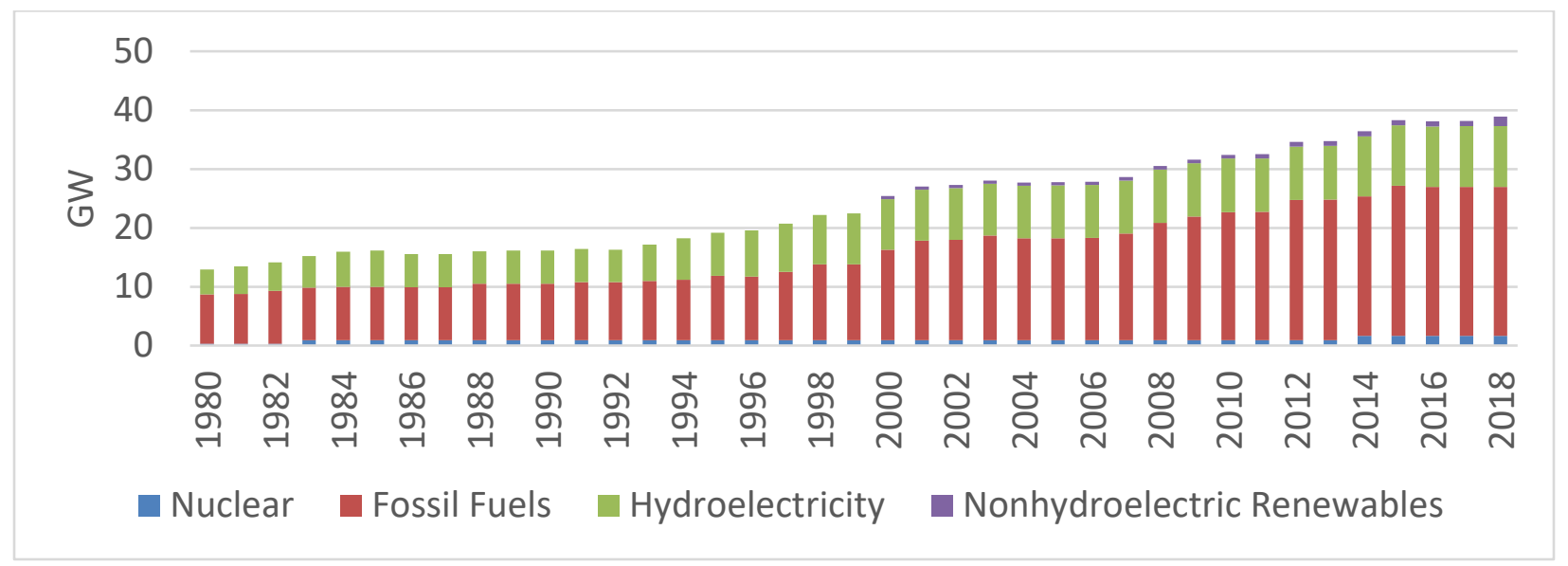

Figure 4. Argentine electricity generating capacity, 1980-2018 (EIA data)

Like Brazil, Argentina has been opening and modernizing its power sector over the course of several decades (International Finance Corporation n.d.; Siboldi, Fanelli, and O'Farrell 2019). The country privatized the power sector, established a wholesale market, and created opportunities for infrastructure development and international investment nearly four decades ago through the 1989 State Reform Law (Law No. 23,696) and 1992 Electricity Regulation Law (Law No. 24,065). 
The National Regulatory Commission for Electricity (ENRE) issued principles and guidelines, resulting in regulatory frameworks adopted by each of Argentina's provinces. The Electricity Regulatory Framework was designed to reduce consumer rates, encourage investment, promote competition, and improve the reliability and efficiency of service. Since privatization, generation, transmission, and distribution have been operated as separate businesses.

The wholesale electricity market is regulated by the Secretariat of Renewable Resources and Electricity Market and administered by the Compañía Administradora del Mercado Mayorista Eléctrico SA (CAMMESA). Large users can enter into the market and contract for power directly through power purchase agreements (PPAs) with the generation companies. In addition to the national grid and wholesale market, two distribution companies operate in the federal jurisdiction, and there are distribution companies and municipal or other cooperatives in each of the provinces. Hydroelectric power projects are governed by federal regulators. Provincial regulators largely manage the distribution companies.

Frequent intervention in the market and freezing of tariffs over the last two decades have created a situation in which potential investors are reluctant to develop projects, the national government subsidizes system costs, and the country is importing a high share of the energy it uses - in contrast to being a strong energy exporter two decades ago (Siboldi, Fanelli, and O'Farrell 2019). This has been a challenge that the past and current presidential administrations have worked to address through changes in subsidies, investment in domestic resource exploration (such as the Vaca Muerta natural gas deposit), and the establishment of auctions for efficient procurement of least-cost resources, including renewables (such as the RenovAr auctions) (Barrigh 2020; Siboldi, Fanelli, and O'Farrell 2019).

In 2015, Argentina passed Law 27,191 "Legal Regulations on National Promotion for the Use of Sources of Renewable Energy - Electric Power Generation," which set a goal that $20 \%$ of the Argentine generation matrix should be comprised of renewable energy sources by 2025 , including small-scale hydropower plants (up to $50 \mathrm{MW}$ ). These laws established an auction-mechanism tax incentive to promote renewable energy project investment (further details are included in Appendix C). While 20 small hydroelectric projects won approval in the first three rounds of the RenovAr auctions, transmission capacity limits prevent the broad expansion of the program.

Argentina elected a new government, with President Alberto Fernández and Vice President Cristina Fernández de Kirchner in October 2019. The Fernández government came into power facing two leading energy issues: expanding the capacity of electricity transmission and natural gas transport. The extension of the electricity transmission network is essential for expanding renewable energy development and interconnecting the country.

\subsubsection{Hydropower Projects}

A handful of large hydroelectric projects and several small projects are in various phases of development. After a suspension in late 2016, construction resumed in early 2019 at the USD \$4.8-billion hydropower complex Cóndor Cliff-La Barrancosa in the southern province of Santa Cruz. The project is financed and built by Chinese companies and is planned to start operations by 2024 (Gadea Lara 2020). The project includes the construction of a $500-\mathrm{kV}$ transmission line to interconnect the complex to Argentina's main grid. In September 2019, the government of the Mendoza province tendered the USD \$1-billion, 210-MW Portezuelo del Viento hydropower 
project. In August 2020, the evaluation commission asked the consortium submitting the sole bid to provide more information. As of October 2020, the group planned to begin the evaluation process in late 2020, but there were still issues to be resolved regarding the environmental impact study (Hydro Review 2020a, 2020b). The 75-MW El Tambolar project on the San Juan River is under construction, while another project, the 270-MW Ana Cua addition to the 3,200-MW Yacyreta binational project on the Paraná River, is tied up in court because of disputes about contract awarding (Hydro Review 2020c). A modernization project is also underway at the 1,890-MW Salto Grande hydroelectric plant, which lies on the Uruguay River between Argentina and Uruguay (Hydro Review 2019).

In addition to these larger projects, 20 small hydro projects were awarded through the RenovAr auctions Rounds 1, 2, and 3 (Table 3). RenovAr auctions are likely to focus on smaller projects like these in the near term, given system transmission constraints and overall reduction in demand (BNAmericas 2020b); while small, these projects represent a significant opportunity in some locations.

Table 3. Small-Hydro Projects Contracted Through Argentina's RenovAr Auction Rounds 1, 2, and 3

\begin{tabular}{lc}
\hline Project & MW Potential \\
\hline \multicolumn{1}{c}{ RenovAr Round 1: $\mathbf{5}$ of $\mathbf{2 9}$ projects were } & small hydro \\
Río Escondido & 7 \\
Dique Tiburcio Benegas & 1.65 \\
Canal Cacique Guaymallén - Salto 6 & 1.01 \\
Canal Cacique Guaymallén - Salto 8 & 1.20 \\
Triple Salto Unificado & 0.51 \\
$\quad$ RenovAr Round 2: $\mathbf{9}$ of $\mathbf{8 8}$ projects were small hydro \\
Boca del Rio & 0.5 \\
Cruz del Eje & 0.5 \\
Pichanas & 0.5 \\
Las Tunas & 10 \\
Salto 7 & 1.2 \\
Lunlunta & 6.34 \\
Salto 11 & 0.51 \\
Salto 40 & 0.52 \\
Salto De La Loma & 0.7 \\
$\quad$ RenovAr Round 3: $\mathbf{6}$ of $\mathbf{3 8}$ projects were small hydro \\
La Calera & 3 \\
Tupungato I & 0.99 \\
Tupungato II & 0.99 \\
La Copa & 0.5 \\
Salto 9 & 0.99 \\
Campo Alegre & 0.91 \\
\hline & \\
&
\end{tabular}




\subsubsection{Recent Developments}

Multiyear economic instability, challenging international debt negotiations, and the COVID-19 pandemic have had a devastating effect on Argentina's economy. While there have been promising events, such as Argentina's negotiation of an international debt repayment plan, inflation and poverty are increasing, and there is much concern about lasting instability and recession. These circumstances and their effects on the potential for hydropower development are described in greater detail in Appendix C.

\subsubsection{Opportunities Summary}

Near-term opportunities for U.S. companies in Argentina may be limited to upgrades or retrofits to existing facilities or the fostering of future partnerships with Argentine companies. In the longer term, there will likely be hydropower development opportunities either through a return to the RenovAr auctions or through direct investment activities of the Argentine government and provinces. Large-scale regional transmission expansion activities may open additional doors to new project development. As in Brazil, reduced energy demand in Argentina due to COVID-19 may mean that project developers should keep a close eye on the Argentine socioeconomic situation, consulting the factors detailed in Section 5 below, to inform any development decisions. In particular, decisions about contract currency terms will strongly affect the potential future risk associated with project investments. The future of the RenovAr auctions, or any mechanism that replaces it, is critical to project decisions. Additionally, the development of the Vaca Muerta shale play is worth watching because it may impact opportunities for hydropower development. 


\section{Industry Survey}

\subsection{Survey Overview}

As part of this project, NREL conducted a survey of renewable energy project developers in Latin America using two interview/survey templates. One was used for U.S. companies that do (or could do) work in Latin America. The second was used for companies that reside in Latin America. Having two separate surveys allowed for different perspectives to be captured, the former being a perspective as to why a company does or does not do work in Brazil or Argentina, and the latter being a perspective about how receptive entities that reside in these countries are to U.S. companies doing business in the region. The survey and interview questions are included in Appendices A and B.

\subsection{Interviews Conducted}

Interviews were conducted using the aforementioned questions with the organizations provided in Table 4.

Table 4. Organizations Interviewed and Location

\begin{tabular}{ll}
\hline Organization [number of people interviewed if multiple] & Location \\
\hline Embassy of the United States of America, Buenos Aires [2] & Latin America \\
\hline EPE (Energy Research Agency) Brazil [2] & Latin America \\
\hline GE & USA \\
\hline HDR & USA \\
\hline IEEE & Latin America \\
\hline Knight Piesold & USA \\
\hline PSR (Consulting company) and ONS (System Operator) & Latin America \\
\hline (one interviewee representing both entities) & USA, formerly in Latin America \\
\hline Pacific Northwest National Laboratory (former consultant) & USA, formerly in Latin America \\
\hline Segrity [2] & Latin America \\
\hline Stantec & Latin America \\
\hline U.S. Department of Commerce U.S. Consulate General & USA \\
\hline Voith & USA, formerly in Latin America \\
\hline Voith (second interviewee from Voith) & Latin America \\
\hline WEG, Brazil & USA \\
\hline World Trade Center Denver &
\end{tabular}

Additional discussions were held on-site at the $3^{\text {rd }}$ Latin American Energy Summit, which took place in Santiago, Chile, on October 16 and 17, 2019, which added to our depth of understanding for this project. After the beginning of the COVID-19 pandemic, the team held another round of informal discussions with staff from the U.S. Embassy and U.S. Commercial Service/Office of International Trade in Argentina and Brazil, domestic U.S. Commercial Service, and World Trade Center, as well as industry representatives, to gauge changes affecting industry opportunities. 


\subsection{Interview Results}

The results from the interviews and surveys were organized into themes that arose as predominant issues, based on three main aspects, including: (i) competition, (ii) social, environmental, political, and hydrological issues, and (iii) project opportunities. The following subsections describe the results.

\subsubsection{U.S. Company-Focused Interviews}

U.S company interviews were held primarily over the telephone in 2019 and in person at the 2019 Hydrovision International conference in Portland, Oregon. For U.S. companies, according to interviewees, the major competitors are local companies that have financial advantages because of import duty structures, as well as better positioning with other industry players incountry; and Chinese companies, that can take advantage of a low cost of capital. Interviewees pointed out that China is acquiring some Brazilian hydropower companies. Other potential competition identified included European and Russian companies.

Social and environmental opposition is a key issue for the development of hydropower projects, particularly in Brazil. Thus, to avoid public opposition, new projects should focus on areas that are not agricultural, inhabited, or culturally or environmentally sensitive. Moreover, in recent years, Brazil has faced drought problems (e.g., significant reductions in regional annual precipitation), which constitutes an additional risk for the viability of hydroelectric generation. Additionally, hydropower investment in Argentina is not attractive given the ongoing political and economic instability.

Broadly, investments in large hydropower units in South America were characterized by several interview respondents as not attractive for several reasons, including social and environmental issues, and long payback periods in comparison with wind and solar projects. Therefore, it seems that opportunities are concentrated in small-scale projects (e.g., $1 \mathrm{MW}$ to $200 \mathrm{MW}$ ), which are mainly run-of-river hydropower. However, the Brazilian hydropower market is saturated and there are more opportunities for new projects in the wind, solar, and natural gas markets. Additionally, there are opportunities associated with engineering services and technology support. It is noteworthy that for U.S. companies there are more attractive opportunities in other countries, including Peru and Colombia (countries in which U.S. companies are currently involved in hydropower projects).

\subsubsection{Latin America Company-Focused Survey Results}

A survey was conducted in November and December 2019 using a database of energy companies based in Latin America or with interest in the Latin American market (see Appendices A and B for survey questions that were prepared in Survey Monkey, with 27 responses received). Almost half of the companies that participated in the survey had investments or plans to invest in the energy sectors in Brazil and Argentina, with a slight majority in the latter of these markets. This may be a reflection of the success of the RenovAr and Mater programs carried out by the former government of President Mauricio Macri to develop Argentina's renewable energy generation capacity. Most of the investments attracted by these programs - worth about USD \$7 billionwere in wind and solar. 
Regarding hydropower projects, less than half (45\%) of the companies surveyed were considering this kind of technology. We can assume that most of these plans are focused on the Brazilian market because there are only 14 small hydropower projects totaling $32 \mathrm{MW}$ in Argentina's projects database. $40 \%$ of survey participants said they plan to explore, or are exploring, hydropower projects of more than $100 \mathrm{MW}$, while $35 \%$ are planning to invest in projects between $10 \mathrm{MW}$ and $20 \mathrm{MW}$. In Brazil, plants with a capacity between $5 \mathrm{MW}$ and 30 MW are considered small hydropower, and benefit from renewable energy incentives.

Most of the projects considered (71\%) were run-of-river projects, which is a growing trend because of the social and environmental problems faced by large hydropower dam projects and the lower initial investment costs of run-of-river configurations. Key drivers for the size and type of run-of-river projects are the companies' financial capacity and the availability of water resources.

Political risks are the main factor that prevents project developers from investing in Argentina or Brazil. Pending changes in Argentinian electricity sector rules under the new government, after four years of a business-friendly administration, are part of this consideration. In lieu of development projects in Argentina and Brazil, many companies are focusing their investments on projects located in Chile, Peru, and Colombia, which maintain market-supportive policies and stable regulations.

The majority of the companies surveyed say that they assess whether or not to invest by considering the whole project lifecycle, not just the initial investment. Inflation and economic stability are important factors regarding the investment strategies of the companies surveyed, but also political factors. More than $90 \%$ answered that they follow the election processes in order to evaluate the risks for their business.

\subsection{COVID-19 Pandemic Period Interviews}

Subsequent to the start of the COVID-19 pandemic, the project team held conversations with U.S. Embassy staff and representatives of the U.S. Commercial Service/Office of International Trade in Argentina and Brazil-as well as representatives of U.S. industry and the international trade organizations that serve them. ${ }^{12}$ Additionally, the team reviewed a host of available materials addressing the effects of COVID-19 on the economies, societies, and specifically the energy sectors of Brazil and Argentina (Barral 2020; BNAmericas 2020a; Tissot and Martin 2020; United Nations 2020).

Themes are identified here, and specific COVID-related barriers and solutions are described in the Mitigation Pathways section below. In Latin America, multiyear economic contractions are expected, which would continue to result in decreased electricity demand and potential domestic economic instability. Countries are taking on high levels of national debt in order to provide their citizens and companies with financial relief. Nations may respond to the structural weaknesses of global dependency by prioritizing domestic supply chains and domestic industry and engineering solutions (even if they might not be the least-cost solutions). Unfortunately, domestic companies struggling to survive the economic challenges of the pandemic may disappear, consolidate,

\footnotetext{
${ }^{12}$ Including the World Trade Center, Office of International Trade, and U.S. Commercial Service domestic office.
} 
relocate to other countries, or may be purchased by international actors, including Chinese companies. Energy professionals across all renewable technologies expressed confidence in supply chains, project construction, and delivery timelines, but economic contractions and reduced demand - as well as a focus on economic and health crises-are likely to cause auctions and other procurement options to be delayed, fewer in number, and more competitive. Globally, there is some focus on clean energy development or climate change action as a tool of economic recovery from the devastation of the pandemic, but it is not clear that this is an active focus in Brazil or Argentina. 


\section{Decision Framework}

As described in previous sections, there are a range of factors that influence energy development decisions in Brazil, Argentina, and Latin America more broadly. These factors are present in normal conditions and are exacerbated during times of social and economic stress, such as the COVID-19 pandemic. The factors presented in the framework below outline critical considerations that U.S. developers should evaluate to inform and assess project investment decisions in Latin America. This framework was developed using results from project interviews, market research, and NREL experience from past projects. The framework can be used to help project developers consolidate options and evaluate opportunities relative to one another. This framework is presented as a guide; investors will ultimately need to assess their own risks and development priorities to determine which locations, markets, and energy technologies provide the best entry into Latin America.

Decision framework criteria are grouped into two categories, or what are referred to as "static" and "dynamic" influences (Figure 5). These groupings are used to characterize the range of considerations, including technical, policy, social, and economic barriers, that can be used to inform investment decisions. These categories were created to recognize that some of the factors that inform project development decisions are more static or slower to change, such as energy resource potential or the location of sensitive habitats. Other factors are more dynamic in nature and subject to more frequent change as a result of influences such as shifts in the geopolitical climate, economic conditions, and social and environmental movements. These factors can be used to guide developers and identify areas where they should seek more specific data, analysis, and market insights. The sections below provide a framework for the static and dynamic factors that can be used to inform hydropower and pumped hydropower storage project developer decisions in the Latin America region.
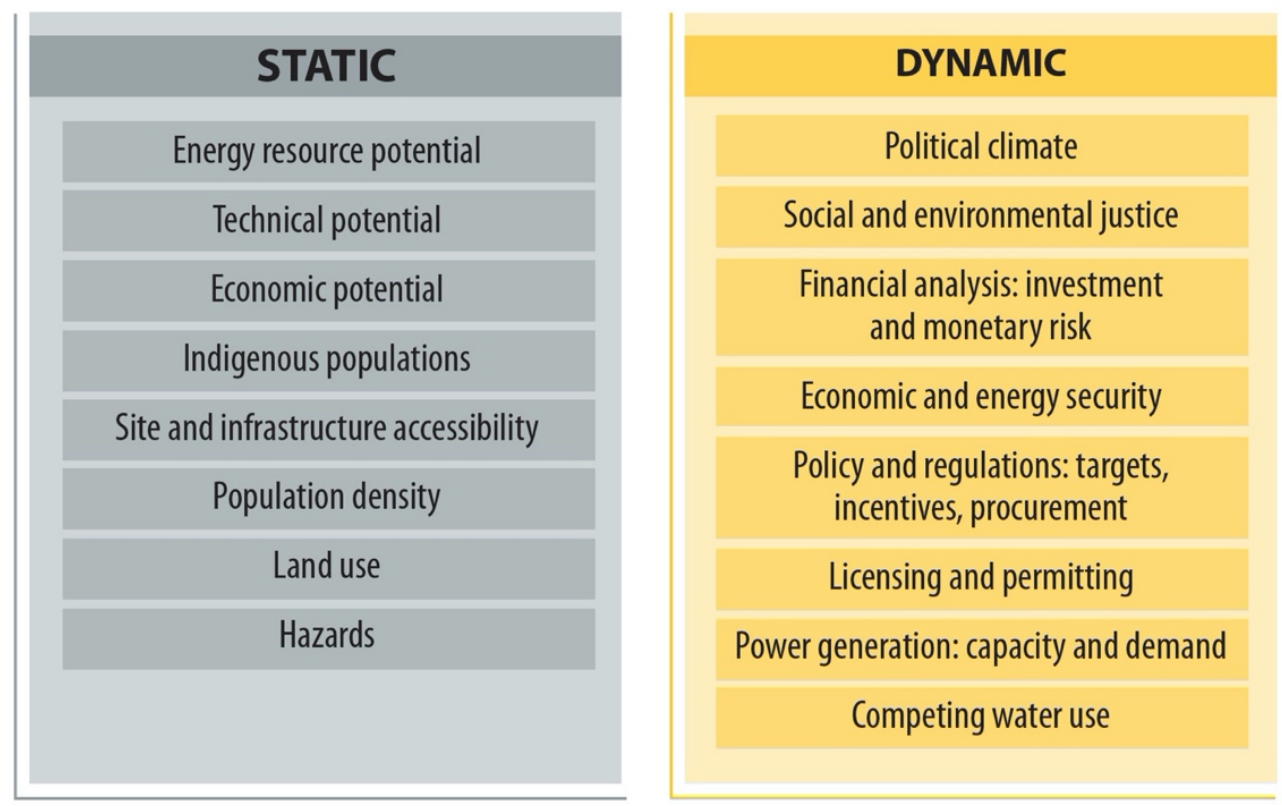

Figure 5. Summary of static and dynamic factors in decision framework 


\subsection{Static Factors: Informing Locations and Technologies}

As mentioned, static factors provide essential data that can be used to help narrow an investor's focus to a particular region or location that is favorable for project development. These factors are typically not subject to frequent change. The factors presented in Table 5 outline the range of criteria to consider when evaluating suitable locations for project development and the deployment of hydropower technologies. Many of these factors can be assessed using geospatial data sets. Where available, these data have been noted in the description below.

Table 5. Static Decision Criteria

\begin{tabular}{|c|c|}
\hline Factor & Description \\
\hline $\begin{array}{l}\text { 1. Energy } \\
\text { Resource } \\
\text { Potential }\end{array}$ & $\begin{array}{l}\text { A measure of the availability of renewable energy resources in a particular } \\
\text { location, typically measured using geospatial data. This factor helps identify } \\
\text { areas with favorable hydropower resources, including hydrology, } \\
\text { watersheds, and rainfall, that would be worth closer evaluation for project } \\
\text { development. Section } 2 \text { provides an overview of the availability of } \\
\text { conventional hydropower and pumped storage geospatial data in Argentina } \\
\text { and Brazil. }\end{array}$ \\
\hline $\begin{array}{l}\text { 2. Technical } \\
\text { Potential }\end{array}$ & $\begin{array}{l}\text { Provides an indication of how a particular hydropower or pumped } \\
\text { hydropower technology might perform in a given location. This factor } \\
\text { accounts for topographic, land use, and system performance constraints } \\
\text { taking available geospatial data into account (see Section 2). }\end{array}$ \\
\hline $\begin{array}{l}\text { 3. Economic } \\
\text { Potential }\end{array}$ & $\begin{array}{l}\text { An estimate of projected technology costs for a particular location, including } \\
\text { capital costs and operations and maintenance (O\&M). Economic potential is } \\
\text { influenced by energy resource availability and the technical potential of a } \\
\text { particular location. These costs are typically calculated as part of the life } \\
\text { cycle costs used to evaluate a project's financial viability. }\end{array}$ \\
\hline $\begin{array}{l}\text { 4. Indigenous } \\
\text { Populations }\end{array}$ & $\begin{array}{l}\text { In Latin America, indigenous populations account for } 8 \% \text { of the region's } \\
\text { population (de Dios 2020); while in Argentina indigenous communities make } \\
\text { up about } 3 \% \text { of country area, in Brazil that figure is } 23 \% \text { (Rights and } \\
\text { Resources } 2015 \text { ). Indigenous communities have cultural and land resources } \\
\text { that are both unique and intrinsic to their way of life. These communities } \\
\text { often lack representation, so it is important to understand their interests and } \\
\text { needs if developing a project in or near their communities. }{ }^{13} \text { As will be } \\
\text { discussed in Section } 6 \text {, most governments require social and environmental } \\
\text { impact assessments to be conducted. Geospatial data, as mentioned in } \\
\text { Section } 2 \text {, is another resource that can be used to identify sensitive areas } \\
\text { and communities that should be avoided for project development. Additional } \\
\text { consideration should also be given to engage with affected indigenous } \\
\text { communities to both understand and work with them to address any potential } \\
\text { impacts and concerns associated with project development. }\end{array}$ \\
\hline
\end{tabular}

${ }^{13}$ For example, see the United Nations' guideline on Free, Prior and Informed Consent (FPIC): https://www.un.org/development/desa/indigenouspeoples/publications/2016/10/free-prior-and-informed-consent-anindigenous-peoples-right-and-a-good-practice-for-local-communities-fao/ 


\begin{tabular}{|c|c|}
\hline Factor & Description \\
\hline $\begin{array}{l}\text { 5. Site and } \\
\text { infrastructure } \\
\text { accessibility }\end{array}$ & $\begin{array}{l}\text { A key consideration for project development is accessibility of existing } \\
\text { infrastructure. This includes factors such as accessibility of existing } \\
\text { roadways for construction and O\&M as well as access to and capacity of } \\
\text { existing infrastructure, such as transmission lines. Geospatial data sets for } \\
\text { existing electrical infrastructure and generation facilities, discussed in } \\
\text { Section } 2 \text {, as well as resources like OpenStreetMap, }{ }^{14} \text { can be used to } \\
\text { screen potential locations for hydropower project development. An additional } \\
\text { consideration is the existence of infrastructure to support the demand for } \\
\text { energy and energy access in particular locations, which is discussed further } \\
\text { as part of the dynamic factors. }\end{array}$ \\
\hline $\begin{array}{l}\text { 6. Population } \\
\text { Density }\end{array}$ & $\begin{array}{l}\text { Used as an indication of areas that may or may not be favorable for project } \\
\text { development. While developing a project near population centers may } \\
\text { provide ready workforce and supply chain access for construction and O\&M } \\
\text { activities, it may also be an indication of the potential for project opposition } \\
\text { depending on the views of that community. Population densities, along with } \\
\text { infrastructure data, can also help identify areas lacking access to energy, } \\
\text { which might be favorable for project development. This factor must be } \\
\text { weighed against other social, economic, and environmental considerations } \\
\text { to inform project decisions. Global population density data are available from } \\
\text { Oak Ridge National Laboratory's LandScan in geospatial format. }{ }^{15}\end{array}$ \\
\hline 7. Land Use & $\begin{array}{l}\text { It is important for the development of hydropower projects to navigate } \\
\text { around and within existing land uses, such as habitats and ecosystems, } \\
\text { cultural or heritage sites, and agricultural lands. The Latin American region is } \\
\text { home to more than } 30 \% \text { of the world's plant and animal species, many of } \\
\text { which remain undiscovered (Moyer 2018). This wealth of biodiversity- } \\
\text { including wetlands, forests, and unique terrestrial and aquatic wildlife as well } \\
\text { as cultural resources- }- \text { has been captured in geospatial data sets such as } \\
\text { Protected Planet }{ }^{16} \text { and the World Database on Protected Areas. }{ }^{17} \text { These } \\
\text { sensitive environments, protected areas, and cultural resources should be } \\
\text { identified in project social and environmental impact assessments to either } \\
\text { avoid or mitigate impacts when developing projects. The location of other } \\
\text { land cover, such as agricultural areas, is also important to assess to } \\
\text { understand areas that potential projects may need to avoid or could } \\
\text { potentially work with as energy offtakers. Land cover data are available from } \\
\text { sources such as the European Space Agency. }{ }^{18}\end{array}$ \\
\hline
\end{tabular}

${ }^{14}$ Available at https://www.openstreetmap.org/\#map=4/38.01/-95.84

${ }^{15}$ Available at https://landscan.ornl.gov/

${ }^{16}$ Available at https://www.protectedplanet.net/

${ }^{17}$ Available at https://www.iucn.org/theme/protected-areas/our-work/world-database-protected-areas

${ }^{18}$ Available at http://due.esrin.esa.int/page_globcover.php 


\begin{tabular}{|c|l|}
\hline Factor & Description \\
\hline 8. Hazards & $\begin{array}{l}\text { Project locations should consider the potential for natural hazards, whether } \\
\text { due to existing risks or climate change projections. Global geospatial data } \\
\text { are available for threats such as wildfires, landslides, earthquakes, and } \\
\text { volcanos through sources such as the U.S. Geological Survey (USGS). }\end{array}$ \\
$\begin{array}{l}\text { Global circulation models can be used as a resource to understand climate } \\
\text { change projections such as precipitation changes or drought, that would } \\
\text { affect the success and longevity of a hydropower project. Regional data are } \\
\text { available through sources such as the National Aeronautics and Space } \\
\text { Administration's (NASA's) Socioeconomic Data and Applications Center } \\
\text { (SEDAC). }{ }^{20}\end{array}$ \\
\hline
\end{tabular}

A geospatial tool, such as the Renewable Energy (RE) Data Explorer, ${ }^{21}$ can be used to overlay and characterize the range of static factors described in this section to identify promising areas for hydropower project development. The RE Data Explorer can be used to analyze renewable energy potential and inform decision making by helping to visualize geospatial data on energy resources, the environment, constituencies, infrastructure, and grid conditions. The tool also supports analysis on factors such as technical and economic potential to help users assess policy or project development decisions. The tool has been developed for numerous countries worldwide, including Mexico, Dominican Republic, Colombia, and Peru. RE Data Explorer has been developed with support from the U.S. Agency for International Development and NREL and can be expanded and tailored to incorporate additional countries and factors to support decision-maker objectives.

\subsection{Dynamic Factors: Shaping Investment Decisions}

Notably, there are many dynamic factors that are prone to rapid change and influenced by unanticipated events. In addition to technical and economic criteria, there are several political and institutional factors an investor would want to understand and consider in the decisionmaking or due-diligence processes. It is important to assess the country risk to understand the unique investment climate within a country under consideration. ${ }^{22}$ Dynamic influences that can factor into country risk are listed in Table 6. Detailed information covering the various factors offered in this table are also discussed in the International Finance Corporation (IFC) Hydroelectric Power Guide for Developers and Investors. ${ }^{23}$

\footnotetext{
${ }^{19}$ Available at: https://www.usgs.gov/news/usgs-authors-new-report-seismic-hazard-risk-and-design-south-america

${ }^{20}$ Available at:

https://sedac.ciesin.columbia.edu/data/collection/nagdc/maps/gallery/search?facets=region:south\%20america\&facets $=$ theme:climate

${ }^{21}$ For more information, see: https://www.re-explorer.org/.

${ }^{22}$ Country risk refers to the economic, political, and business risks that are unique to a specific country and that might result in unexpected investment losses.

${ }^{23}$ Available at: https://www.ifc.org/wps/wcm/connect/906fa13c-2f47-4476-9476-

75320e08e5f3/Hydropower_Report.pdf?MOD=AJPERES\&CVID=kJQ135z
} 
Table 6. Dynamic Decision Criteria

\begin{tabular}{|c|c|}
\hline Factor & Description \\
\hline 1. Political Climate & $\begin{array}{l}\text { It is important for investors to understand the political climate of a country } \\
\text { when assessing investment risks. Internal conflicts, geopolitical tensions, } \\
\text { and government corruption all contribute to political instability. An unstable } \\
\text { political environment is a significant risk for investors that can impede } \\
\text { energy investment and have a negative effect on an investment destination. } \\
\text { Sudden or impending changes in government leadership, policies, and } \\
\text { conditions create uncertainties and increase risks that drive down investor } \\
\text { confidence. Political stability and government backing can enable conditions } \\
\text { that support institutional innovation and positive policy actions that provide a } \\
\text { stable environment for investors. Notably, it is also important to evaluate and } \\
\text { understand the political economy (how politics and the economy affect each } \\
\text { other) of a country or region. More information on the political economy of } \\
\text { hydropower can be found in the report, Internationalizing the Political } \\
\text { Economy of Hydroelectricity: Security, Development and Sustainability in } \\
\text { Hydropower States. }{ }^{24}\end{array}$ \\
\hline $\begin{array}{l}\text { 2. Social and } \\
\text { Environmental } \\
\text { Justice }^{25}\end{array}$ & $\begin{array}{l}\text { As noted in Table 5, indigenous populations can be significantly impacted } \\
\text { when development occurs within or near their communities. Such negative } \\
\text { impacts include involuntary displacement of populations that can lead to } \\
\text { socioeconomic problems and human rights infringements, such as } \\
\text { homelessness, landlessness, and reduction or loss of income. In the case of } \\
\text { displacement, generally with large hydropower projects, resettlement plans } \\
\text { must be included in the project plan. It is important to realize and factor in } \\
\text { these potential impacts when deciding on hydropower investment and site } \\
\text { locations and related investment. There are also positive impacts to } \\
\text { consider. Renewable energy projects, such as hydropower, can support } \\
\text { sustainable development by reducing effects of energy poverty through } \\
\text { access to clean modern energy and electricity services that bolster } \\
\text { economic, social, and environmental well-being. In essence, project } \\
\text { investors should evaluate where negative consequences could occur, and } \\
\text { where their investments will benefit populations. There are organizations, } \\
\text { such as GlobalDamWatch, }{ }^{26} \text { that maintain public records of all existing and } \\
\text { planned dams and of existing or proposed hydroelectric projects that pose } \\
\text { environmental justice issues. }\end{array}$ \\
\hline $\begin{array}{l}\text { 3. Financial } \\
\text { Analysis: } \\
\text { Investment and } \\
\text { Monetary } \\
\text { Risks }\end{array}$ & $\begin{array}{l}\text { The financial analysis of a project evaluates its potential profitability } \\
\text { examining the revenues and costs. There are a number of economic } \\
\text { productivity and transactional costs to evaluate when assessing financial } \\
\text { viability of a project, such as inflation rates, payback periods, import duties, } \\
\text { currency risks and exchange rates, market conditions, adequate work/labor } \\
\text { force and skills capacity, and a range of external benefits and costs, such as } \\
\text { reduced health costs, improved air quality, and sedimentation impacts. }\end{array}$ \\
\hline
\end{tabular}

\footnotetext{
${ }^{24}$ Available at: https://www.tandfonline.com/doi/pdf/10.1080/09692290.2018.1511449?needAccess=true

${ }^{25}$ Capital costs can increase due to environmental or social considerations, such as resettlement. For more information, see: https://www.ifc.org/wps/wcm/connect/906fa13c-2f47-4476-9476-

$75320 \mathrm{e} 08 \mathrm{e} 5 \mathrm{f3} /$ Hydropower Report.pdf?MOD=AJPERES\&CVID=kJQ135z.

${ }^{26}$ For more information, see: http://globaldamwatch.org.

${ }^{27}$ For example, see: https://ejatlas.org.
} 


\begin{tabular}{|c|c|}
\hline Factor & Description \\
\hline $\begin{array}{l}\text { 4. Economic and } \\
\text { Energy } \\
\text { Security }\end{array}$ & $\begin{array}{l}\text { Hydropower technologies have the potential to improve economic and } \\
\text { energy security across multiple countries within a region. These needs are } \\
\text { amplified in an age of rising uncertainties caused by such things as weather- } \\
\text { related events and other natural disasters, cybersecurity threats, and the } \\
\text { COVID-19 pandemic. One example of how hydropower can provide } \\
\text { increased economic and energy security and resilience is through cross- } \\
\text { border power trades, which also offer economic opportunities for investors. } \\
\text { Experiences in Nepal provide a compelling case study on successful cross- } \\
\text { border trading of hydropower (Hotchkiss, Cox, Stout, Hurlbut, and Gevorgian } \\
2019 \text { ). However, it is critical to understand the geopolitics of the area, the } \\
\text { policy and regulatory frameworks, and resilience planning for each country } \\
\text { involved. It is also important to identify threats and vulnerabilities to the } \\
\text { power systems in each country. Cross-border power trade can support } \\
\text { hydropower development across a region, while offering a pathway to } \\
\text { economic and energy security and resilience (Timilsina 2018). }\end{array}$ \\
\hline $\begin{array}{l}\text { 5. Policy and } \\
\text { Regulations: } \\
\text { Targets, } \\
\text { Incentives, } \\
\text { Procurement }\end{array}$ & 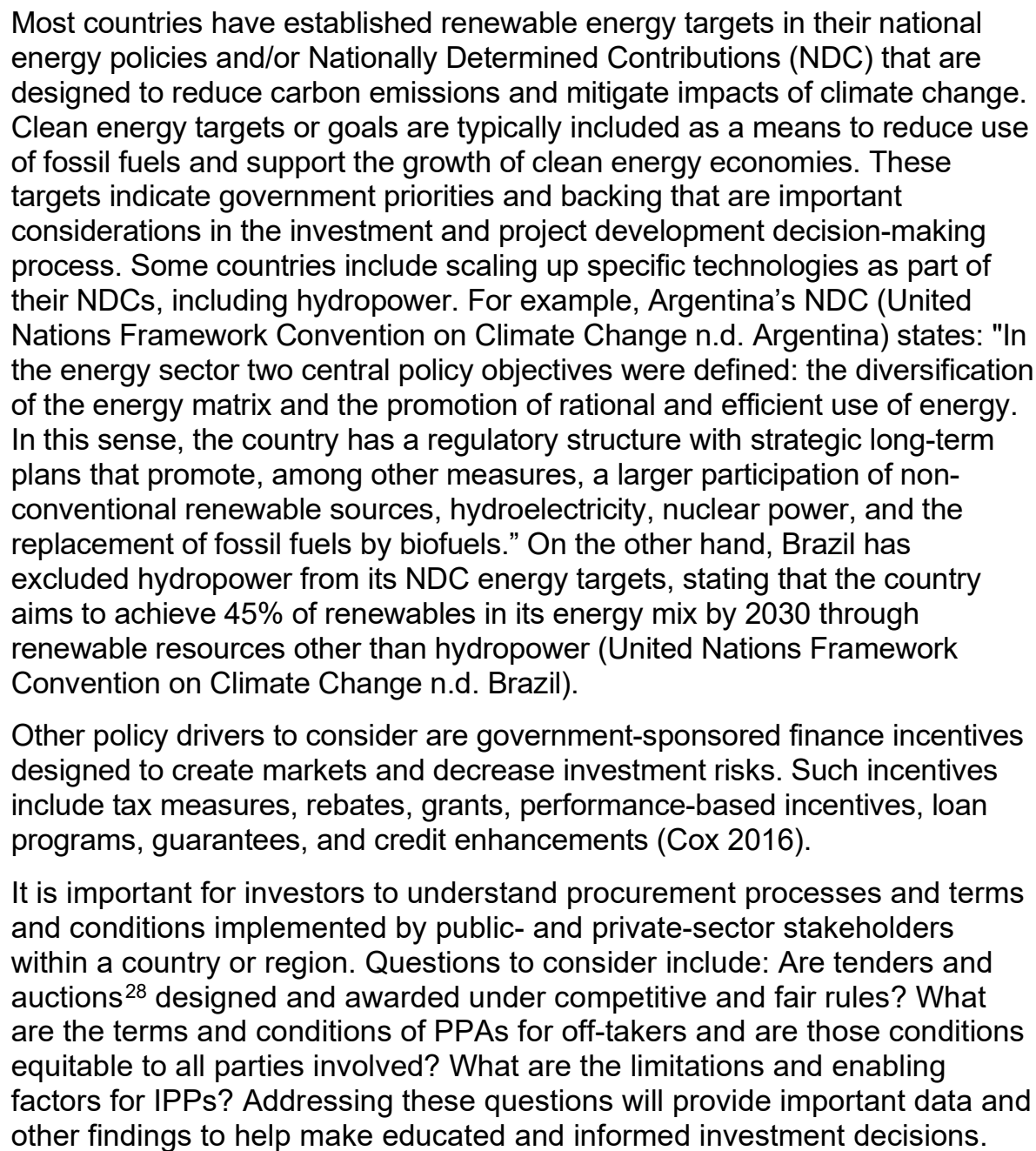 \\
\hline
\end{tabular}

${ }^{28}$ For more information, see: $\underline{\mathrm{https}} / / / \mathrm{cleanenergysolutions.org/instruments/tenders-reverse-auctions.}$ 


\begin{tabular}{|c|c|}
\hline Factor & Description \\
\hline $\begin{array}{l}\text { 6. Licensing and } \\
\text { Permitting }\end{array}$ & $\begin{array}{l}\text { Licensing and permitting is a complex process that involves multiple } \\
\text { agencies and approvals leading to high potential for costly delays. Risk } \\
\text { mitigation involves understanding specific project requirements, engaging } \\
\text { early with the relevant agencies as well as the local community and other } \\
\text { affected stakeholders, and collaborating with experienced local partners or } \\
\text { consultants. Some things to consider in this process include environmental } \\
\text { and social impact assessments; project specification factors; material } \\
\text { sourcing and supply chain requirements; project size/capacity and siting } \\
\text { restrictions; and, specifically for hydropower, whether there is a requirement } \\
\text { or restriction on the project type (e.g., impoundment, diversion, and pumped } \\
\text { storage hydropower). }\end{array}$ \\
\hline $\begin{array}{l}\text { 7. Power } \\
\text { Generation: } \\
\text { Capacity and } \\
\text { Demand }\end{array}$ & $\begin{array}{l}\text { It is important to consider both the capacity and demand for electricity when } \\
\text { assessing the viability of a potential project. Investors should consider } \\
\text { installed energy generation and transmission capacity as well as data on } \\
\text { existing and future energy demand. Other factors to assess are: existing } \\
\text { production/generation fuels in use and associated supply and costs; how } \\
\text { much fuel is imported versus domestic sources; grid capacity and } \\
\text { infrastructure conditions and their ability to accommodate additional power; } \\
\text { demand factors based on power consumption in normal conditions and in } \\
\text { times when demand would increase or decrease because of sudden } \\
\text { disruptions such as natural disasters or economic downturns. For example, } \\
\text { while many countries in Latin America have been projecting growth in } \\
\text { energy demand, due to COVID-19, demand has currently decreased. The } \\
\text { IEA has examined the COVID-19 crisis on global energy demand and } \\
\text { reported its findings (International Energy Agency 2020). It will be important } \\
\text { for investors to monitor this situation to determine the need and timing of } \\
\text { new energy projects. }\end{array}$ \\
\hline $\begin{array}{l}\text { 8. Competing } \\
\text { Water Use }\end{array}$ & $\begin{array}{l}\text { Water serves multiple needs for human subsistence and development } \\
\text { beyond providing for energy needs. In the context of a changing climate, } \\
\text { there is increasing demand for water and increasing uncertainty in both its } \\
\text { timing and the quantity available. While hydropower projects can help with } \\
\text { flood control and energy generation, there are often tradeoffs between using } \\
\text { water to generate energy versus its use for agricultural irrigation, drinking } \\
\text { water, recreation, fishing, and tourism. Investment decisions should include } \\
\text { consideration of multipurpose schemes that accommodate the community's } \\
\text { needs and allow for multiple water uses. These needs and mitigation } \\
\text { strategies should be identified in the project's social and environmental } \\
\text { impact assessments and may require the use of hydro-economic models } \\
\text { (Gonzalez et al. 2016; Mendes, Leme de Barros, Zambon and Yeh 2015). }\end{array}$ \\
\hline
\end{tabular}

While these dynamic factors are more difficult to visualize, there is potential to expand the RE Data Explorer to include a decision-making platform. This platform could incorporate selected dynamic inputs to guide investors through these critical considerations. The platform could also perform calculations on economic and technical potential, such as energy output measurements, levelized cost of energy, capital costs associated with environmental and social considerations, such as resettlement plans, and cross-border trading revenue potential. The platform would interact with the visualization components of the RE Data Explorer to provide decision makers with a robust, integrated, and informative decision framework. 


\section{Barriers to Hydropower Projects and Mitigation Pathways}

Building on the information in the decision framework, this project identified a number of potential barriers that U.S. companies might face when considering hydropower development in Argentina and Brazil (Table 7), and established a mitigation pathways library to address these challenges. The challenges specific to COVID-19 impacts (right column in Table 7) are characterized as near term or long term based on the assessment of industry analysts and experts.

Table 7. Barriers to Hydropower Development in Brazil and Argentina

\begin{tabular}{|l|l|}
\hline $\begin{array}{l}\text { General Challenges to Hydroelectric } \\
\text { Development for U.S. Companies in Latin } \\
\text { America }\end{array}$ & Challenges Specific to COVID-19 Effects \\
\hline $\begin{array}{l}\text { Lack of experience with the market and the } \\
\text { domestic finance structures and opportunities }\end{array}$ & $\begin{array}{l}\text { Near term: Economic contraction and reduced } \\
\text { electricity demand }\end{array}$ \\
\hline $\begin{array}{l}\text { Lack of on-the-ground knowledge and } \\
\text { operations }\end{array}$ & $\begin{array}{l}\text { Near term: Slowdown of government processes } \\
\text { and work schedules }\end{array}$ \\
\hline Finance and economic challenges & $\begin{array}{l}\text { Long term: Reduced globalization or increase in } \\
\text { nationalist industrial policy }\end{array}$ \\
\hline $\begin{array}{l}\text { Competition of U.S. entities with Chinese } \\
\text { entities }\end{array}$ & $\begin{array}{l}\text { Long term: Economic instability or currency } \\
\text { fluctuations due to increased national debt }\end{array}$ \\
\hline $\begin{array}{l}\text { Unemployment and shortage of skilled labor } \\
\text { near project sites }\end{array}$ & $\begin{array}{l}\text { Long term: Socioeconomic or governmental } \\
\text { structural shortcomings highlighted by COVID }\end{array}$ \\
\hline $\begin{array}{l}\text { Project-level opposition due to environmental, } \\
\text { social or cultural impacts }\end{array}$ & $\begin{array}{l}\text { Long term: Support programs suspended; } \\
\text { changes in policy priorities }\end{array}$ \\
\hline
\end{tabular}

\subsection{Mitigation Pathways}

A collection of strategic activities may be beneficial to overcoming existing barriers and fostering U.S. hydropower activity in Brazil and Argentina. For each of these barriers, the following sections identify the critical factors that might be overcome, strategic approaches, and detailed activities involved or resources that could be deployed in implementing a mitigation strategy. These are the beginning elements of a potential Mitigation Strategies Library that can be explored in depth for each development challenge and updated or maintained over time.

\subsubsection{Lack of Experience With the Market and Domestic Finance Structures or Opportunities}

U.S. companies, particularly if they operate in many countries, may not have recent experience with the domestic market mechanisms, options for selling power, or the finance structures available in each country. Additionally, these market opportunities and finance mechanisms can change quickly. 


\section{CASE STUDY: SEGRITY}

SEGRITY (Services with Integrity; segrity.com), a global engineering consulting firm, was established in 2012 to provide services to the hydroelectric industry. The company serves clients in the United States and international markets, including Latin America, deploying tailored generator governor and control systems to upgrade and optimize the operation of existing hydroelectric facilities. Like many U.S. companies, SEGRITY found that tapping into the enormous global potential for hydropower development or facility upgrades was not without its challenges. Changes to import/export rules and other laws governing international commerce, a lack of on-the-ground operations and associated business connections, and the general logistical difficulties associated with deploying infrastructure changes in another country are some of the key obstacles that companies like SEGRITY constantly work to overcome.

Fortunately, a number of U.S. government agencies and international trade organizations have services in place to address these challenges. The World Trade Center Denver (WTCD) provided the SEGRITY team with the tools they needed to educate themselves about, and be compliant with, the complexities of international trade law, and connected SEGRITY with other organizations and consultants who could assist in different spaces where WTCD did not work directly. SEGRITY participated in an 'emerging leaders in exports' program through the Minority Business Office of Colorado (a program of Colorado's Office of Economic Development and International Trade, OEDIT), in which they developed a plan for export activities, participated in a pitch competition, and were selected and funded to complete WTCD training programs and perform international business development visits and activities. Through these training and funding opportunities, the CEO and VP of engineering received the WTC Certificate of International Trade in 2019. Additionally, SEGRITY solidified a strategic alliance with a Canadian company, exhibited at HydroVision International 2019, and visited potential customers in South America, increasing company revenues by $5 \%$ in international sales.

Another agency supporting U.S. companies' international success is the U.S. Commercial Service (USCS, under the U.S. Department of Commerce, International Trade Administration), which has Export Assistance Centers and industry specialists posted in more than 100 U.S. cities. Through its GoldKey service, the Assistance Centers can coordinate commercial visits to a specific country, for example, organizing trips for companies to travel abroad to meet potential customers; the Assistance Center and its counterparts at the embassies abroad serve as the link between U.S. companies and potential partners, customers, or clients in target countries. This local expertise has insights into the economic strengths and industry specialty of specific companies and can make introductions where the result will be most promising for the U.S. company. The USCS' targeted market intelligence can also be summarized in a report for companies that do not need the full GoldKey service. By coordinating between U.S. and embassy offices, the USCS engages in commercial diplomacy, advocating for U.S. companies that are dealing with financial or legal challenges with partners or clients abroad. Finally, the programs also help with business etiquette and other informal training to help U.S. actors be more successful in all of their encounters with potential customers or partners on the ground in target countries.

The National Hydropower Association, the International Hydropower Association, and similar organizations can support education and outreach efforts to U.S. and other international companies promoting investment opportunities and providing updates on the changing landscapes in Brazil and Argentina. Additionally, the U.S. Commercial Service and embassies aim to stay on top of, and serve as resources for businesses on, changes in markets and government policy on topics such as financing, public-private partnerships, etc. More information about these services is provided in the following section.

\subsubsection{Lack of On-the-Ground Knowledge and Operations}

U.S. companies may be at a distinct disadvantage compared to domestic actors in Brazil or Argentina because of unfamiliarity with laws and procedures for international trade or operations in-country and due to lack of knowledge of domestic companies with whom they might partner or that might be ideal target clients. Additionally, regulations governing import/export and finance are often changing, both in the United States and in the target countries. Export logistics are complicated, and international project financing can be difficult to structure because of the changing legal landscape and the sheer time embedded in business transactions that involve 
shipping parts or equipment between multiple countries. Further, the path for a U.S. company to move a project concept to the energy auction table is not a straightforward process.

The World Trade Centers, U.S. Commercial Service, U.S. International Development Finance Corporation, organizations such as Denver's Office of International Trade, and in-country embassies support U.S. companies in overcoming these hurdles. These organizations help U.S. companies navigate complex international and relevant domestic laws in Argentina and Brazil, and they stay abreast of changes in law and their significance for U.S. actors. These organizations can support companies with identification of, and introductions to, key partners or clients, helping U.S. companies develop the relationships critical to establishing business opportunities or advancing projects abroad. Additionally, there are tools available through these agencies to help companies identify global market potential on their own. ${ }^{29}$

U.S. companies can use these services to develop an Argentine or Brazilian customer base or business partnerships - whether as an equipment supplier, technical advisor, construction firm, or collaborator - to develop or advance new projects. Working with in-country partners, U.S. companies are much more likely to be able to develop a project that can bid into and execute contracts in Argentina or Brazil's domestic auction processes.

Further, in the case where U.S. companies do not feel they can participate in international energy auctions on their own, these services can support the companies in developing partnerships with local companies to jointly propose projects that are competitive in a country's auction.

U.S. industry should be aware of, and take advantage of, the programs and services offered by these agencies and organizations. Efforts can be made to support their offerings by broadcasting available support services through events, presentations, and webinars. There may be other opportunities worth exploring to build the relationship between industry and these support services - this can be posed to the stakeholder community to discover new, innovative opportunities.

\subsubsection{Finance and Economic Challenges}

Larger hydroelectric projects face challenges obtaining financing and up-front capital, as well as revenue uncertainty, because of changes in currency valuation, inflation, and economic fallout related to issues such as the COVID-19 pandemic.

Multiple interview respondents, mentioned in Section 4, advocated for partnering with a large infrastructure project and energy user, such as mining, manufacturing, or smelting activities, in order to have a guaranteed long-term energy demand and "deep pockets" with which to finance the hydroelectric project to meet this load. Partnering with these entities enables companies to 'bring their own load' along with a project proposal and avoid having to compete in an auction or other mechanism of the power market.

Some of the finance mechanisms and domestic policies to support them are discussed in the decision framework in Section 5. Addressing the entire breadth of current challenges of

\footnotetext{
${ }^{29}$ For example, see the Market Diversification Tool: https://beta.trade.gov/MarketDiversificationTool.
} 
international finance and economic instability in Argentina and Brazil merits a discussion beyond the scope of this project.

\subsubsection{Geopolitical Barriers}

Large infrastructure projects are frequently developed in partnership with foreign investors or aid programs. As an example, China is able to offer extremely low interest rates for financing infrastructure projects as part of its international aid programs. This can create a challenge for U.S. companies seeking to engage in the hydropower sector, but there are a number of programs specifically designed to support U.S. company or investor competitiveness.

Private financing, host-country-bank financing, and U.S. government financing options exist for infrastructure projects. Examples include Export-Import (EXIM) Bank, the U.S. International Development Finance Corporation, and in-country sources such as the Brazilian National Development Bank (BNDES), which all offer lending alternatives.

The U.S. Trade and Development Agency (USTDA) offers global procurement initiatives to support best practices in identifying value while achieving infrastructure development. Additionally, USTDA can support U.S. industry with grants for feasibility studies or technical assistance for priority infrastructure projects in partner countries. USTDA launched a partnership with Brazil in 2017 to provide training to Brazil's procurement workforce.

The Export-Import Bank of the United States (EXIM Bank), which finances the export of U.S. goods and services, has a track record of financing hydropower projects, including the Itaipu Dam in Brazil and the Yacyreta Dam in Argentina. EXIM Bank provides low-interest loans and loan guarantees backed by the U.S. government.

The U.S. International Development Finance Corporation (DFC) is the U.S. government's development bank. DFC partners with the private sector to finance infrastructure solutions in emerging economies in the energy, health care, critical infrastructure, and technology sectors. Importantly, DFC lending standards include measures to ensure respect for the environment, human rights, and worker rights, providing emerging economies with "financially sound alternatives to unsustainable and irresponsible state-directed initiatives." 30

\subsubsection{Unemployment and Shortage of Skilled Labor Near Project Sites}

The development of hydropower projects requires a significant amount of labor in comparison to other types of renewable energy projects. However, driven by the lack of local skilled workers, most of these job opportunities are taken by outsiders (Calvi et al. 2019; Moran et al. 2018; Fearnside 2014).

Additionally, most of the labor is required during the dam construction process. Therefore, after the dam is built, job opportunities tend to diminish in the near term (e.g., within five years). A focused effort could be instituted to train local residents on the O\&M of the hydropower project to provide more enduring benefits to the local workforce and economy. Capacity building can

\footnotetext{
${ }^{30}$ For more information, see https://www.dfc.gov/who-we-are.
} 
become a critical component of a project and a social responsibility of the project's industry participants.

\subsubsection{Project-Level Opposition Caused by Environmental or Cultural Impacts}

Hydropower projects could face social opposition from different actor groups, including environmental justice organizations, local neighbors, farmers, indigenous groups, and social movements, among others (Scheidel et al. 2020; Kaneti 2019; Temper et al. 2018). Opposition to hydropower projects may have a variety of drivers, including socioeconomic issues (e.g., displacement of surrounding communities, loss of landscape and sense of place, and livelihood loss), environmental issues (e.g., aesthetic degradation, biodiversity loss, and large-scale disturbance of hydrogeological systems), and health issues (e.g., mental health and accidents) (Temper et al. 2018; Shah, Vos, Veldwisch, Boelens and Duarte-Abadía 2019). It is noteworthy that governance plays an important role in addressing hydropower's social and environmental issues (Moran et al. 2018; Athayde et al. 2019). For example, local communities or organizations typically do not have a significant role in the decision-making process of hydropower projects. This can result in regional or local priorities being ignored and the interests of hydropower developers being prioritized. Additionally, while large hydropower projects are often promoted with the suggestion that local communities will reap some benefits from these projects, empirical evidence indicates otherwise (Calvi et al. 2019). Hydropower projects are often developed to serve energy users and economic sectors outside the region where these projects are located. Moreover, social opposition can take different forms involving formal petitions, public campaigns, street protests, development of collective action networks, involvement of nongovernmental organizations, media-based activism, and lawsuits, among others (Scheidel et al. 2020).

Different actions or mitigation pathways can be implemented to address social, environmental, and sustainability issues around hydropower projects (Pérez-Rincón et al. 2019):

- First, social impact assessments (SIAs) and environmental impact assessments (EIAs) need to be rigorous so as to identify critical aspects that should be addressed in hydropower project development. For example, SIAs and EIAs should be carried out early enough in project development to provide an appropriate assessment that has the capability to halt the development of the hydropower project if social and environmental costs are not acceptable or cannot be effectively addressed to meet the needs of the community.

- SIAs and EIAs, which are usually required by the government, should be performed by organizations or consulting firms coordinated by regulating agencies rather than the hydropower developers. However, current practice indicates that SIAs and EIAs are typically performed by consulting firms or organizations hired by hydropower developers. Thus, there can be a lack of transparency regarding the data and results associated with SIAs and EIAs for new hydropower projects. A national policy of early, integrated planning that includes transparent consultation with all stakeholders supports a robust process for identifying project roadblocks and prioritizing viable projects.

- Designs of hydropower facilities should mimic the seasonal river flows and allow for fish passage. For instance, greater attention should be given to advanced designs that allow running fish to spawn and prevent adverse effects to aquatic species. 
- Better governance needs to be established around hydropower projects. For example, there is a need for more holistic approaches to assess and quantify the tradeoffs associated with hydropower projects and the use of water for energy generation, food production, drinking water, sanitation, recreation, and the environment.

- According to the United Nations Declaration of the Rights of Indigenous Peoples, ${ }^{31}$ states should consult with indigenous communities regarding potential projects. There should be greater transparency with local communities and society concerning the true benefits and costs of hydropower projects. Indeed, there is a need to incorporate how national or regional energy policies affect local environmental, social, and health issues in the design, development, and operation of hydropower facilities.

- The evaluation of hydropower projects should incorporate sustainability assessment measures, such as the Dam Environmental Vulnerability Index (DEVI), from the design of the dam through its operation (Latrubesse et al. 2017).

- There should be application and continued innovation of hydropower technologies that do not involve damming the river or relocating population, including in-stream turbine technologies, in order to mitigate social, environmental, and health issues associated with hydropower developments.

\subsubsection{Covid-19-Driven Challenges}

The COVID-19 pandemic crisis has caused significant socioeconomic hardships at the individual, corporate, and national levels worldwide: families out of work are challenged to cover living costs, including power bills; electricity generation owners and power companies are facing slowdowns in construction activities, reductions in energy demand, and challenges in managing remote operations; and economic recessions are forcing government changes in policies, such as those regarding currency exchange, creating challenges for foreign firms.

\subsubsection{Short-Term Challenges}

\section{Near-Term Economic Constriction and Delay in Government Processes or Work Schedules}

As a result of the shutdowns and cascading declines in economic activity, economic constrictions and necessary changes in processes to protect public health may cause a number of immediate challenges to hydropower development.

For projects that are underway, immediate risks include the slowdown of domestic government processes needed to advance projects, such as environmental studies and permitting, the slowdown of construction work due to health precautions and border closures, and an increased timeframe needed for near-term future construction due to concerns about worker health.

For projects still in the conceptual or development phase, these challenges include fewer opportunities for new projects to sell into the power system due to decreased electricity demand and domestic economic instability, which may result in delayed or canceled auctions and a reduced appetite among other potential markets such as mining or industry. Additionally, early-

\footnotetext{
${ }^{31}$ See https://www.un.org/development/desa/indigenouspeoples/declaration-on-the-rights-of-indigenouspeoples.html
} 
stage projects face potential investment slowdowns due to lack of liquidity or increased concern about risks. There is also a challenge for existing projects that were contemplating refinancing in order to upgrade or modernize aging equipment or processes.

With respect to mitigation, hydropower's flexibility services have been in high demand during the COVID-19 crisis, while plant operations have been less affected than some other types of power plants due to the degree of automation in modern facilities (International Hydropower Association 2020a). This positions hydropower plants well relative to other potential new sources of generation. Nevertheless, if there is no demand for new power, new projects will only be constructed to address issues of aging infrastructure or to support distributed generation. Developers can attempt to partner with industry on the development of new projects to meet localized demand, to work around the lack of government auctions, and pursue smaller-scale projects that are relatively simpler to develop and easier to permit and construct.

\subsubsection{Longer-Term Challenges}

\section{Decreased Globalization/Nationalist Industrial Policy}

Because of the concern about COVID-19 and other potential future pandemics, there is significant discussion surrounding policy development to decrease globalization and dependence on foreign supply chains. This would change the global dynamics that have supported economies in countries that previously embraced industrialization, multinational trade agreements, and economic reforms. In order to minimize the vulnerabilities of globalization realized during the pandemic, politicians may institute more protectionist policies favoring local manufacturing, which could further threaten international involvement in the energy sectors of Latin America.

With respect to mitigation, if national policy is structured to favor local content, contractors, and operators, U.S. companies can work to build development partnerships with local companies or can establish in-country operations. They can also play the role of investor, but the risks associated with this may be high, given current and likely near-term economic conditions in Brazil and, particularly, in Argentina.

In recent years, China has increased its foreign direct investment in the power generation, utilities, and infrastructure sectors in Latin America, and its emergence from COVID-19 earlier than the U.S. and Europe could provide China with an advantage in exploiting investment opportunities in Latin America, particularly in acquiring financially vulnerable companies or through opportunities to invest in infrastructure. China's financial strength and positioning could result in increasing geopolitical influence, amplifying a trend that was already underway before COVID-19 (Tissot and Martin 2020).

Another challenge is the unprecedented levels of national debt across Latin America, taken on to rescue communities and businesses during the shutdowns, which could have macroeconomic impacts for years, both hindering economic growth and boosting inflation. These factors may reduce electricity demand, consequently decreasing the market for additional development of generating capacity and creating an unstable fiscal environment in which to do business and contract for long-term energy sales.

With respect to mitigation, companies involved in hydropower generation should coordinate with national policy. Where small- to medium-scale hydropower projects make financial and 
operational sense, hydropower developers might seek to partner with companies and institutions to develop additional projects. At the same time, performing upgrades and renovations to existing hydropower can make older plants more efficient and cost-effective as well as more resilient to future system shocks.

\section{Socioeconomic and Governmental Structural Failures}

The COVID-19 crisis has highlighted socioeconomic disparities and structural shortcomings of governments, and there are efforts in place to develop economic 'rescue' packages that also address other current social issues such as economic disparities, or future challenges that nations will face such as climate change. Argentina and Brazil have both instituted some measure of economic stimulus or regulation in order to mitigate COVID-19's negative effects (See Appendix C).

Energy planning can be a powerful tool for addressing socioeconomic disparities or structural shortcomings. ${ }^{32}$ By providing reliable information to decision makers and the private sector for navigating uncertainties and complexities, the energy planning arena can provide common ground for debate and consensus-building. This can be used to bring together civil society, the corporate sector, and government, potentially speeding up positive transitions necessary for decarbonization while also yielding a safer environment for investment in infrastructure. At the same time, the [Brazilian] government's large investments made to support the economic recovery could be used to tackle its social issues agenda in order to resolve multiple problems at the same time. These might include the clean energy transition, increased social equity, and other economic and environmental issues facing societies. Carefully planned reforms, informed by the perspectives of all elements of society, may help the government to more efficiently tackle these issues while supporting economic recovery.

In its policy brief on responding to the pandemic, the International Hydropower Association encouraged hydroelectric developers to get projects shovel-ready, to use international standards and best practices for sustainability, and to work with international financing institutions to get hydroelectric projects into governmental rescue infrastructure packages (International Hydropower Association 2020b). Similarly, in its reporting on the effects of the pandemic and the responses of Latin American governments, the Institute of the Americas suggested that the climate change crisis requires that pandemic economic responses be used to support and accelerate an energy transition (Tissot and Martin 2020). These solutions are of course broadly recommended and not specific to Brazil or Argentina.

\footnotetext{
32 The perspectives in this paragraph are based on comments from Thiago Barral, the director of EPE, the Brazilian national energy planning agency, during the webinar hosted by IAmericas and CEBRI "Brazil: Energy Reflections and Perspectives" held on July 15, 2020. Available at https:/www.iamericas.org/events/energy-reflections-andperspectives/
} 


\section{Key Findings}

Each element of this project yielded specific results or findings, as summarized in Table 8 .

Table 8. Key Findings From Each Project Element

\begin{tabular}{|c|c|}
\hline Project Element & Key Findings \\
\hline $\begin{array}{l}\text { Geospatial and } \\
\text { resource data sets }\end{array}$ & $\begin{array}{l}\text { Available data sets confirm that there is abundant technical potential for } \\
\text { hydropower development at all scales and pumped hydroelectric project } \\
\text { development in both Argentina and Brazil. }\end{array}$ \\
\hline $\begin{array}{l}\text { Country policy, } \\
\text { economics, and power } \\
\text { system regulation and } \\
\text { infrastructure }\end{array}$ & $\begin{array}{l}\text { Policies and economic or regulatory structures support limited development of } \\
\text { hydropower projects, particularly where there is complementarity with variable } \\
\text { generation and access to transmission infrastructure. Additional transmission } \\
\text { buildout, advances in hydropower technology, decarbonization goals and } \\
\text { electricity market reform will support further hydropower development. } \\
\text { Economic instability due to COVID-19 and other domestic challenges, } \\
\text { particularly in the case of Argentina, increase investment risk for U.S. and } \\
\text { other foreign companies or financers. }\end{array}$ \\
\hline $\begin{array}{l}\text { U.S and Latin } \\
\text { American Company } \\
\text { Industry Interviews }\end{array}$ & $\begin{array}{l}\text { Development opportunities are often limited to smaller projects, run-of-river } \\
\text { technologies, and retrofits to existing facilities in both countries in the near } \\
\text { term. Political and economic instability in Argentina, drought in Brazil, and the } \\
\text { longer payback periods than for wind or solar projects limit industry and } \\
\text { financial institution interest in these markets. Particularly in Brazil, the } \\
\text { domestic industry is strong and may limit opportunities for U.S. companies to } \\
\text { engineering services or technology support. In both countries, local } \\
\text { companies have a clear advantage and thus business relationships with } \\
\text { domestic companies may be important for entering the market. Latin } \\
\text { American companies may be more apt to invest in projects in Chile, Peru or } \\
\text { Colombia due to favorable markets and regulations (which, of course, can } \\
\text { change at any time). }\end{array}$ \\
\hline Decision Framework & $\begin{array}{l}\text { Investment decisions are influenced by the region's environment, economic } \\
\text { landscape, social constraints, policies, and technical or power system } \\
\text { dynamics. These considerations can be categorized into static or dynamic } \\
\text { factors. Developers should determine or consult the current status of our list } \\
\text { of static and dynamic factors to support their decision process. Tools such as } \\
\text { the RE Data Explorer can be updated as factors evolve, in order to provide } \\
\text { nimble, ongoing support to the decision process. }\end{array}$ \\
\hline Mitigation Strategies & $\begin{array}{l}\text { There are mitigation strategies that can be explored for the key barriers to } \\
\text { hydropower development in each country. Some of these strategies are more } \\
\text { well-developed than others. }\end{array}$ \\
\hline Next Steps & $\begin{array}{l}\text { This project can be expanded more broadly to other countries or regions or } \\
\text { can dive more deeply into the details influencing investment decisions in } \\
\text { Brazil or Argentina. A high priority next step is to determine the information } \\
\text { necessary to expand decision support tools such as the RE Data Explorer for } \\
\text { these two or other high-priority development countries in Latin America. }\end{array}$ \\
\hline
\end{tabular}




\section{Suggested Next Steps}

This project has gathered informative data over an extremely volatile period of time, because of the COVID-19 pandemic. The hope is that the resource data, situational data, decision framework and mitigation library can be used as a hub of information to inform and support the U.S. hydropower industry's business decisions concerning Brazil and Argentina. There is much more that can be done to further this goal of U.S. hydropower industry involvement in Latin America. Some initial thoughts and recommendations are:

- Continue industry surveys to gauge changes in opportunity over time and particularly with respect to anticipated effects of the COVID-19 pandemic. This could be coupled with a webinar series to ensure a robust exchange of information and continued development of the Mitigation Strategies Library.

- Conduct a similar opportunity assessment in other Latin American energy markets, including Colombia, Peru, and/or Chile. Colombia represents the third largest hydropower country in Latin America, while Chile and Peru are in the top five of hydropower capacity added. In addition, the Peruvian government has expressed its commitment to become self-sufficient in energy by 2040, leading to several hydropower plants expecting to enter into operations in the coming years. There is also a trend of companies beginning to focus their investments on Chile, Peru, and Colombia, due to their pro-market policies and more stable regulations.

- Expand the Brazil/Argentina decision framework to include more on the role of hydropower (and pumped storage hydropower) as the grid becomes more dominant with renewable energy in Latin America.

- Present this work at Hydrovision International, and/or the World Hydropower Congress, or other similar venue to gather feedback and refine.

- Develop a geospatial tool such as the U.S. Agency for International Developmentsupported, NREL-developed RE Data Explorer, ${ }^{33}$ to include a decision-making platform to, apart from resource potential, factor in the static and dynamic inputs discussed within Section 5 of this report and provide calculations on economic and technical potential, such as energy output measurements, levelized cost of energy, capital costs associated with environmental and social considerations, such as resettlement plans, and crossborder trading revenue potential. The decision platform would interact with the visualization components of the RE Data Explorer to provide decision makers with a robust, integrated, and informative decision framework that would account for both static and dynamic factors that influence project development.

${ }^{33}$ Available at: https://www.re-explorer.org/ 


\section{References}

Athayde, Simone, Mason Mathews, Stephanie Bohlman, Walterlina Brasil, Carolina R. C. Doria, Jynessa Dutka-Gianelli, et al. 2019. "Mapping research on hydropower and sustainability in the Brazilian Amazon: advances, gaps in knowledge and future directions." Curr. Opin. Environ. Sustain. 37: 50-69. https://doi.org/10.1016/j.cosust.2019.06.004.

Barral, Thiago. "Energy: Reflections and Perspectives.” Webinar from IAmericas/CEBRI/BMA/Catavento. July 15, 2020. https://www.iamericas.org/events/energyreflections-and-perspectives/.

Barrigh, Jorge. "Renewables in Argentina, Trends, Expectations, and Investment Perspectives." Webinar from IAmericas. April 30, 2020. https://www.iamericas.org/events/webinarrenewables-argentina-trends-expectations-investment-perspectives/

Beluco, Alexandre, Paulo K. de Souza, and Arno Krenzinger. 2008. "A dimensionless index evaluating the time complementarity between solar and hydraulic energies." Renewable Energy, 33: 2157-2165. https://doi.org/10.1016/j.renene.2008.01.019.

BNAmericas. 2020a. "Electric Power Capex 2020: The key trends among operators in Latin America and the impact of COVID-19." Webinar, June 16, 2020.

https://www.youtube.com/watch?v=jL8bqNAsG98.

BNAmericas. 2020b. "Argentina power watch: Renewables tender, new energy minister, Atucha III.” August 21, 2020. https://www.bnamericas.com/en/news/argentina-power-watchrenewables-tender-new-energy-minister-atucha-iii.

Brasil Ministerio de Minas e Energia, Empresa de Pesquisa Energética. 2019. "The 2029 TenYear Energy Expansion Plan Executive Summary." https://www.epe.gov.br/sites-en/publicacoesdados-abertos/publicacoes/PublicacoesArquivos/publicacao-

212/Executive\%20Summary\%20PDE\%202029.pdf.

Brasil Ministerio de Minas e Energia, Empresa de Pesquisa Energética. 2020a. "PDE 2030 Avaliação do Suprimento de Potência no Sistema Elétrico e impactos da Covid-19 REV." PowerPoint Presentation. https://www.epe.gov.br/sites-pt/publicacoes-dadosabertos/publicacoes/PublicacoesArquivos/publicacao-490/topico-522/PDE\%202030\%20$\% 20$ Avaliação $\% 20 \mathrm{do} \% 20$ Suprimento $\% 20 \mathrm{de} \% 20$ Potência $\% 20$ no $\% 20$ Sistema $\% 20$ Elétrico $\% 20 \mathrm{e}$ \%20impactos $\% 20 \mathrm{da} \% 20$ Covid-19\%20REV.pdf.

Brasil Ministerio de Minas e Energia, Empresa de Pesquisa Energética. 2020b. "Caderno de Demanda de Eletricidade - PDE 2030." PowerPoint Presentation. https:/www.epe.gov.br/sitespt/publicacoes-dados-abertos/publicacoes/PublicacoesArquivos/publicacao-490/topico522/Caderno $\% 20 \mathrm{de} \% 20$ Demanda $\% 20 \mathrm{de} \% 20$ Eletricidade $\% 20-\% 20 \mathrm{PDE} \% 202030 \% 20(1)$.pdf.

Brasil Ministerio de Minas e Energia, Empresa de Pesquisa Energética. 2020c. "PNE 2050 Plano Nacional de Energia.” Accessed November 7, 2020. https:/www.epe.gov.br/pt/publicacoesdados-abertos/publicacoes/Plano-Nacional-de-Energia-2050. 
Calvi, Miquéias F., Emilio Moran, Ramon Felipe Bicudo da Silva, Mateus Batistella. 2019. "The construction of the Belo Monte dam in the Brazilian Amazon and its consequences on regional rural labor." Land Use Policy 90 (C): 104327. https://doi.org/10.1016/j.landusepol.2019.104327.

Campos do Prado, Josue, Jeffrey Logan, and Francisco Flores-Espino. 2019. Options for Resilient and Flexible Power Systems in Select South American Economies (Technical Report). Golden, CO: National Renewable Energy Laboratory (NREL). NREL/TP-6A50-75431. https://www.nrel.gov/docs/fy20osti/75431.pdf.

Canineu, Maria Laura and Sônia Guajajara. "Europe Can Help Us Save the Amazon." Human Rights Watch (blog). July 31, 2020. https://www.hrw.org/news/2020/07/31/europe-can-help-ussave-amazon\#.

Cantão, Mauricio P., Marcelo R. Bessa, Renê Bettega, Daniel H. M. Detzel, and João M. Lima. 2017. "Evaluation of hydro-wind complementarity in the Brazilian territory by means of correlation maps." Renewable Energy, 101: 1215-1225.

https://doi.org/10.1016/j.renene.2016.10.012.

Cox, Sadie. 2016. Financial Incentives to Enable Clean Energy Deployment: Policy Overview and Good Practices (Technical Report. Golden, CO: National Renewable Energy Laboratory (NREL). NREL/TP-6A20-65541. https://www.nrel.gov/docs/fy16osti/65541.pdf.

de Dios, Martín. 2020. "The situation of Latin America's indigenous population and the impact of COVID-19." United Nations Development Program in Latin America and the Caribbean (blog). May 14, 2020.

https://www.latinamerica.undp.org/content/rblac/en/home/blog/2020/impacto-y-situacion-de-lapoblacion-indigena-latinoamericana-ant.html.

Djunisic, Sladjana. 2020."Argentina's renewables boost production by $55.2 \%$ y/y in June.” Renewables Now. July 20, 2020. https://renewablesnow.com/news/argentinas-renewables-boostproduction-by-552-yy-in-june-706952/.

The Economist. "Argentina reaches a deal with its foreign creditors.” August 5, 2020. https://www.economist.com/the-americas/2020/08/05/argentina-reaches-a-deal-with-its-foreigncreditors.

European Union. "In Focus: EU-Mercosur.” Accessed September 15, 2020. https:/ec.europa.eu/trade/policy/in-focus/eu-mercosur-association-agreement/.

Fearnside, Philip M. 2014. "Impacts of Brazil's Madeira River Dams: Unlearned lessons for hydroelectric development in Amazonia.” Environ. Sci. Policy 38: 164-172. https://doi.org/10.1016/j.envsci.2013.11.004.

Fitch Solutions. "Covid-19 Pandemic To Impact Already Weakened Argentine Power Sector." May 12, 2020. https://www.fitchsolutions.com/corporates/utilities-power/covid-19-pandemicimpact-already-weakened-argentine-power-sector-12-05-2020. 
Gillespie, Patrick. "Companies Flee Argentina, and Coronavirus is Just One Reason." Bloomberg Businessweek. July 27, 2020. https://www.bloomberg.com/news/articles/2020-07-27/companiesare-leaving-argentina-and-it-s-not-pandemic-s-fault.

Global Legal Insights. “2020 Brazil Energy chapter.”Accessed September 15, 2020. https://www.globallegalinsights.com/practice-areas/energy-laws-and-regulations/brazil.

Gonzalez, Jose M., Marcelo Olivares, Josué Medellín Azuara, Rodrigo Moreno, and Guilherme ferndandes Marques. 2016. "Multi-Purpose Reservoir Operation: A Tradeoff Analysis between Hydropower Generation and Irrigated Agriculture Using Hydro-Economic Models." In World Environmental and Water Resources Congress, West Palm Beach, FL, May 22-26, 2016, p. 241250. American Society of Civil Engineers, Reston, VA. DOI: 10.1061/9780784479858.026.

Hoes, Olivier A. C., Lourens J. J. Meijer, Ruud J. van der Ent, Nick C. van de Giesen. 2017. "Systematic high-resolution assessment of global hydropower potential." PLOS One 12(2): e0171844. https://doi.org/10.1371/journal.pone.0171844.

Hotchkiss, Eliza, Sadie Cox, Sherry Stout, David Hurtlbut, Vahan Gevorgian. 2019. CrossBorder Power Trade to Support Resilience. Golden, CO: National Renewable Energy Laboratory (NREL). NREL/TP-6A20-75153. https://www.nrel.gov/docs/fy20osti/75153.pdf.

Hydro Review. 2019. "Overhaul to proceed on 1,890-MW Salto Grande hydroelectric plant between Argentina, Uruguay.” March 6, 2019. https://www.hydroreview.com/2019/03/06/overhaul-to-proceed-on-1-890-mw-salto-grandehydroelectric-plant-between-argentina-uruguay/.

Hydro Review. 2020a. "Argentina advances tender for 210-MW Portezuelo del Viento hydro project," July 8, 2020. https://www.hydroreview.com/2020/07/08/argentina-advances-tender-for210-mw-portezuelo-del-viento-hydro-project/\#gref.

Hydro Review. 2020b. "Argentina to resume work to construct 210-MW Portezuelo del Viento hydropower." September 10, 2020. https://www.hydroreview.com/2020/09/10/argentina-toresume-work-to-construct-210-mw-portezuelo-del-viento-hydropower/\#gref.

Hydro Review. 2020c. "Argentina court accepts EBY's 270-MW Aña Cuá hydropower appeal." September 1, 2020. https://www.hydroreview.com/2020/09/01/argentina-court-accepts-ebys270-mw-ana-cua-hydropower-appeal/.

International Energy Agency. 2020. "Global Energy Review 2020: The Impact of the COVID-19 crisis on global energy demand and CO2 emissions." https://www.iea.org/reports/global-energyreview-2020.

International Finance Corporation. N.d. "Scaling Infrastructure: RenovAr (Argentina): Scaling 'Express Edition'.” Accessed September 15, 2020. https://www.ifc.org/wps/wcm/connect/987eeec6-6259-4c00-8e21-fbf49813a47b/scaling-infraargentina-08.pdf?MOD=AJPERES\&CVID=mSCMXzz. 
International Hydropower Association. 2018. "Brazil statistics." Accessed September 15, 2020. https://www.hydropower.org/country-profiles/brazil.

International Hydropower Association. 2020a. 2020 Hydropower Status Report: Sector trends and insights. Accessed September 15, 2020. https://www.hydropower.org/statusreport.

International Hydropower Association. 2020b. "Strengthening sustainable hydropower to support the Covid-19 recovery." May 28, 2020. https://www.hydropower.org/publications/iha-positionpaper-strengthening-sustainable-hydropower-to-support-the-covid-19.

International Renewable Energy Agency. 2015. Renewable Energy Policy Brief: Brazil. IRENA, Abu Dhabi. https://www.irena.org/-

/media/Files/IRENA/Agency/Publication/2015/IRENA_RE_Latin_America_Policies/IRENA_R E Latin America Policies 2015 Country Brazil.pdf.

Kaneti, Marina. 2019. "Dams, neoliberalism, and rights: Mainstreaming environmental justice claims.” Sustain. Dev. 28 (2): 1-11. https://doi.org/10.1002/sd.1996.

Lara, Gadea Tais. 2020. "New Argentina government reactivates controversial Patagonia dams." February 25, 2020. https://dialogochino.net/en/climate-energy/33727-new-argentinagovernment-reactivates-controversial-patagonia-dams/.

Latrubesse, Edgardo M, Eugenio Y. Arima, Thomas Dunne, Edward Park, Fernando d'Horta, et al. 2017. "Damming the rivers of the Amazon basin." Nature 546: 363-369.

doi:10.1038/nature22333. nature.com/articles/nature22333.

Mendes, Ludmilson A., Mario T. Leme de Barros, Reanto C. Zambon, William W-G. Yeh. 2015. "Trade-Off Analysis among Multiple Water Uses in a Hydropower System: Case of São Francisco River Basin, Brazil." Journal of Water Resource Planning \& Management. 141(10): 04015014-1 - 04015014-10. 10.1061/(ASCE)WR.1943-5452.0000527.

Moran, Emilio F., Maria Claudia Lopez, Nathan Moore, Norbert Müller, David W. Hyndman. 2018. "Sustainable hydropower in the 21st century". Proc. Natl. Acad. Sci. 115 (47): 1189111898. https://doi.org/10.1073/pnas.1809426115.

Morais, Lucas. 2015. "Brazil to set 15\% renewable power goal by 2030." Renewables Now. September 16, 2015. https://renewablesnow.com/news/brazil-to-set-15-renewable-power-goalby-2030-493242/.

Moyer, Erika. 2018. "Latin America and International Day for Biodiversity." Natural Resources Defense Council (blog). May 25, 2018. https://www.nrdc.org/experts/erika-moyer/latin-americaand-international-day-biodiversity.

Nascimento, Rodrigo Limp. 2020. "Perspectives and Opportunities in the Power Sector (PowerPoint Presentation).” Brazil Ministerio de Minas e Energia June 17, 2020. 
Pérez-Rincón, Mario, Julieth Vargas-Morales, and Joan Martinez-Alier. 2019. "Mapping and Analyzing Ecological Distribution Conflicts in Andean Countries.” Ecol. Econ. 157: 80-91, https://doi.org/10.1016/j.ecolecon.2018.11.004.

Rights and Resources. 2015. "Who Owns the Land in Latin America?” November 2015. https://rightsandresources.org/wpcontent/uploads/FactSheet_English_WhoOwnstheLandinLatinAmerica_web.pdf

Scheidel, Arnim, Daniela Del Bene, Juan Liu, Grettel Navas, Sara Mingorria, et al. 2020. "Environmental conflicts and defenders: A global overview." Glob. Environ. Change. 63: 102014. https://doi.org/10.1016/j.gloenvcha.2020.102104.

Shah, Esha, Jeroen Vos, Gert Jan Veldwisch, Rutgerd Boelens, Bibiana Duarte-Abadía. 2019. "Environmental justice movements in globalising networks: a critical discussion on social resistance against large dams.” J. Peasant Stud. 6150.

https://doi.org/10.1080/03066150.2019.1669566.

Siboldi, Agustín, Agustina Fanelli, and Estudio O'Farrell. 2019. "Electricity regulation in Argentina: overview." Thomson Reuters Practical Law (blog). August 1, 2019. https://uk.practicallaw.thomsonreuters.com/6-524-0092.

Silva, Allen Rodrigues, Felipe Mendonça Pimenta, Arcilan Trevenzoli Assireu, Maria Helena Constantino Spyrides. 2016. "Complementarity of Brazil's hydro and offshore wind power." Renew Sustain Energy Rev, 56: 413-427. https://doi.org/10.1016/j.rser.2015.11.045.

Soria, Horacio, “Beyond worst nightmares': Argentina's child poverty rate soars amid pandemic.” Reuters, July 5, 2020, https://www.reuters.com/article/us-health-coronavirusargentina-poverty/beyond-worst-nightmares-argentinas-child-poverty-rate-soars-amid-pandemicidUSKBN2460GZ.

Stocks, Matthew, Ryan Stocks, Bun Lu, Cheng Cheng, Anna Nadolny, Andrew Blakers. 2019. "A global atlas of pumped hydro energy storage." Australian National University. https://www.dropbox.com/s/1sfeky0od2amvpd/190606\%20Global\%20pumped\%20hydro\%20Atl as.pdf? $\mathrm{dl}=0$.

Stuenkel, Oliver. 2020. “A Problem for German Trade Ambitions: Brazil's Environment Minister." Americas Quarterly. July 30, 2020. https://www.americasquarterly.org/article/aproblem-for-german-trade-ambitions-brazils-environment-minister/.

Temper, Leah, Federico Demaria, Arnim Scheidel, Daniela Del Bene, Joan Martinez-Alier. 2018. "The Global Environmental Justice Atlas (EJAtlas): ecological distribution conflicts as forces for sustainability." Sustain. Sci. 13: 573-584.

https://link.springer.com/article/10.1007/s11625-018-0563-4.

Timilsina, Govinda R. 2018. "How would cross-border electricity trade stimulate hydropower development in South Asia?" No. WPS8513 Washington, D.C. World Bank Group. http://documents.worldbank.org/curated/en/714401531237858109/How-would-cross-borderelectricity-trade-stimulate-hydropower-development-in-South-Asia. 
Tissot, Rene Roger, and Jeremy M. Martin. 2020. The Day After: Latin America's response to key energy issues Derived from COVID-19. Institute of the Americas, Energy \& Sustainability Program. https://www.iamericas.org/2020/06/11/the-day-after-latin-americas-response-to-keyenergy-issues-derived-from-covid-19/.

United Nations. 2020. "Policy Brief: The Impact of COVID-19 on Latin America and the Caribbean." July 2020. Accessed September 15, 2020. https://unsdg.un.org/resources/policybrief-impact-covid-19-latin-america-and-caribbean.

United Nations Framework Convention on Climate Change. Undated. "Federative Republic of Brazil Intended Nationally Determined Contributions Towards Achieving the Objective of the United Nations Framework Convention on Climate Change.” Accessed September 15, 2020. https://www4.unfccc.int/sites/ndcstaging/PublishedDocuments/Brazil\%20First/BRAZIL\%20iND C\%20english\%20FINAL.pdf.

United Nations Framework Convention on Climate Change. Undated. "Argentine Republic Intended Nationally Determined Contribution." Accessed September 15, 2020. https://www4.unfccc.int/sites/submissions/INDC/Published\%20Documents/Argentina/1/Argenti na\%20INDC $\% 20$ Non-Official $\% 20$ Translation.pdf.

World Bank. 2020. "COVID-19 in Brazil: Impacts and Policy Responses.” July 10, 2020. https://reliefweb.int/report/brazil/covid-19-brazil-impacts-and-policy-responses. 


\section{Appendix A. Latin America Survey Distributed Through Industry Exchange LLC}

NOTE: Results from the survey are available from NREL upon request.

¿Ha invertido o tiene en estudio en invertir en proyectos de energía en estos países? (marque todas las que correspondan). Have you invested or do you have investment plans in energy projects in these countries?

○ Brasil

- Argentina

En caso afirmativo, ¿ha invertido o piensa invertir en proyectos hidroeléctricos en Argentina o Brasil? If yes, have you invested, or do you have investment plans in hydropower projects in Argentina or Brazil?

O Si (Yes)

- No

¿En qué tipo/tamaño de proyectos hidroeléctricos invierte o estudia invertir? (marque todas las que correspondan). What is the scale of the projects in which you have invested or planning to do so?

- Menos de $10 \mathrm{MW}$ de potencia Less than 10MW capacity

- Entre $10 \mathrm{MW}$ y $20 \mathrm{MW}$ Between $10 \mathrm{MW}$ and $20 \mathrm{MW}$

- Entre 20MW y 50MW Between 20MW and 50MW

- Entre 50MW y 100MW Between 50MW and 100MW

- Más de 100MW More than 100MW

¿Cuáles son las principales razones para invertir en este tipo/tamaño de proyectos? (marque todas las que correspondan). What are the main reasons to invest in this type/scale of projects?

- Capacidad de financiamiento/riesgo financiero del proyecto (Budget/ financial risk)

- Enfoque estratégico de su empresa (strategic focus of your company)

- Beneficios tributarios (tax benefits)

- Menores barreras ambientales/sociales (environmental/social issues)

- Disponibilidad de recursos hídricos (availability of hydropower resources)

Si no tiene inversiones en energía en Brasil y Argentina, ¿cuáles son las razones para no haberlo hecho?. If you don't have investments in Brazil and Argentina, what are the reasons for not investing in these countries?

- Problemas de infraestructura de interconexión (interconnection issues)

- Falta de incentivos tributarios (lack of tax and incentives)

- Política energética poco atractiva (unfavorable energy policy)

- Riesgos políticos (political risk)

- Riesgos cambiarios (risk associated with the exchange rate)

- Inestabilidad jurídica (legal instability) 
- Disponibilidad/calidad de los recursos energéticos (availability/quality of the energy resources)

- Otros (especifique, por favor) (other, please specify)

¿En qué países participa en proyectos hidroeléctricos? In which countries are you involved in hydropower projects?
○ Chile
○ Perú
- Bolivia
- Ecuador
- Colombia
- Panamá
- México

¿Cuáles son las principales razones para participar en proyectos hidroeléctricos en esos países? What are the main reasons to be involved in hydropower projects in these countries?

- Tamaño del mercado (market size)

- Marco legal (legal framework)

- Precios de la energía (energy prices)

- Estabilidad política y económica (political and economic stability)

¿Cuáles son las principales barreras para facilitar contratos de suministro binacionales de mediano plazo? What are the main barriers to facilitate medium-term binational supply contracts?

- Riesgo político (political risk)

- Riesgo financiero (financial risk)

- Inestabilidad jurídica (legal instability)

- Ausencia de marco legal/regulatorio (absence of legal/regulatory framework)

- Otros (especifique, por favor) (other, please specify)

¿Cuál el principal factor para evaluar la viabilidad de su proyecto? What is the main factor to assess the viability of your energy projects?

- Inversión inicial (initial investment)

- Inversión en el ciclo completo del proyecto (life cycle investment)

¿Cómo se ve afectada su estrategia de inversiones por la inestabilidad económica y la inflación de un país? How is your investment strategy affected by the economic instability and inflation of a given country?

- Son factores muy importantes (these are very important)

- Son importantes, pero no los únicos (these are important but not the only ones)

- Hay otros factores que son más importantes que estos (there are other factors that are more important) 
¿Hace un seguimiento de las elecciones de autoridades para evaluar su riesgo? Do you track the elections of authorities to assess the investment risk?

- Sí (yes)

○ No

¿Cómo influyen los aranceles de importación y el Impuesto al Valor Agregado en sus decisiones de inversión? How does Value added Tax (VAT) or Import Duty play into your investment decisions?

- Son factores muy importantes (these are very important)

- Son importantes, pero no los únicos (these are important but not the only ones)

- Hay otros factores que son más importantes que estos (there are other factors that are more important)

¿Qué otra información debemos considerara para evaluar las inversiones en hidroelectricidad en Brasil y Argentina? What other information should we consider when assessing hydropower investments in Brazil and Argentina? 


\section{Appendix B. Interview Questions Used With U.S. Industry Representatives}

The following questions were used to perform interviews with members of industry from the United States. Summary notes from the interviews are available from NREL upon request.

Common questions:

- Why do you invest or not invest in Brazil? In Argentina?

- If yes, what types of hydro projects do you invest in? What is your typical project scale?

- Why/why not on types of projects and scale?

- If you do not do work in Brazil and Argentina, reasons for not investing in that region: transmission, incentives, political?

- Where do you currently sell/build/support hydropower projects? Why?

- What are the barriers to facilitate medium-term binational supply contracts?

- How do you assess project viability - initial capital investment of full life cycle cost? Are you owner/operators or are your projects turnkey?

- How do your investment policies relate to economic stability and inflation rate of a region?

- Do you track elections to assess risk?

- Value Added Tax (VAT) and Import Duty_how does this play into investment decisions?

Brazil-specific questions:

- Do you agree with "if you build it, they will come" as it relates to transmission?

- How do plans for capacity expansion in Brazil effect your decision?

- How about the administration's views?

- Do social and environmental opposition play a role in decision making?

- Does centralized dispatch play a role in decision making?

- Do water scarcity issues play a role in decision making?

Argentina-specific questions:

- The regional electricity integration has taken a new momentum, with Argentina a key country in the process. What is necessary to continue advancing in this process? How can U.S. companies leverage/benefit from this momentum?

- What role does the eventual development of an international energy market play for Argentina? 
- How does uncertainty related to natural gas (shale gas) apply to investment decision making? (similar to Colombia)

- Do social and environmental opposition play a role in decision making? Socioeconomic opposition (similar to Colombia)

- In countries such as Argentina, the development of small- and medium-sized projects has continued to grow despite competition from gas, solar, and wind energy. Do U.S. businesses see an opportunity for exploiting hydroelectric potential as an enabler for other renewables in this region? What does the sector need to continue to develop and become the back-up alternative for wind and solar energy?

In-country-specific questions:

- Do Brazilian or Argentinian companies have advantages (benefits, incentives, tax breaks for local content, etc.) when participating in hydropower projects in Brazil/Argentina?

- How easy is it to partner with American companies?

- What do you think of the pumped storage potential in Brazil or Argentina? What are the main barriers/challenges for greater development?

- Does your company and its national competitors have a product portfolio for pumped storage power plants?

- In your opinion, what types of hydropower projects have more potential to be developed in Brazil or Argentina (micro hydro ( $<5 \mathrm{MW})$, small hydro $(<30 \mathrm{MW})$, or large power plants $(>30 \mathrm{MW}))$ ?

- Is there any aspect of hydropower that cannot be done in Brazil and/or Argentina? E.g., lack of skills or workforce.

- Are there any reasons to typically prefer U.S./ China / Europe in terms of partnering with foreign companies to aid hydropower development?

- What is your view on the long-term economic potential for hydropower in Brazil and Argentina? 


\section{Appendix C. Brazil and Argentina Background and Energy Landscape}

This appendix includes additional material that was gathered in developing the high-level overviews presented in the report.

\section{C.1 Electricity Market and Renewables Regulation in Brazil}

Brazil was one of the first countries in Latin America to implement a public policy to support the development of renewables, including small-scale hydropower plants, from $1 \mathrm{MW}$ to $30 \mathrm{MW}$ (International Renewable Energy Agency 2015). The Alternative Energy Source Incentive Program (PROINFA) launched in 2002 with the goal of developing 3,300 MW of wind, solar, and small-hydro capacity through the use of tax benefits, financial support from the state-owned Brazilian National Development Bank (BNDES), and a 20-year PPA with state-owned electric power company Eletrobras. Under PROINFA, 63 small-scale hydropower plants were approved, with a total capacity of $1.2 \mathrm{GW}$. As of October 2019,54 of these plants were selling electricity to Eletrobras, the national electric company.

Subsequent to the implementation of PROINFA, Brazil established capacity auction mechanisms in 2004 and 2007; the latter specifically allowed auctions exclusively for renewables. Auctions typically take place twice a year for procurement of new generating capacity. Brazil also created funding options and preferential financing for renewable energy through the Energy Development Fund (CDE), the BNDES, and the Innova Energia (2013) program to subsidize research and development projects using cutting-edge technologies for decarbonization of all energy use sectors (International Renewable Energy Agency 2015). Other financing mechanisms, funds, and fiscal incentives, such as tax exemptions, are also in use in Brazil. In 2015, Brazil approved Public Law 433 amending the 2002 Law 10,438 to mandate that specific renewables (small hydro, wind, and solar) meet $10 \%$ of generation by 2022 and $15 \%$ by 2030 (Morais 2015). Most of the new hydropower projects in Brazil use run-of-river configurations with small reservoirs.

\section{C.2 Recent Developments in Brazil}

\section{Electricity Market Reform}

An electricity market modernization bill that allows small consumers to participate in the free power market, regardless of their load or voltage, was approved in the Senate in 2020 and would become law if approved by the Chamber of Deputies.

This law, PLS 232, would strengthen the free energy market and enable consumer choice of electricity supplier (Nascimento 2020). The law strives to implement a coordinated market opening by respecting legacy contracts while it establishes new methodologies for allocation of costs and risks among power system participants. The law would review the operation and price formation models in order to establish hourly locational tariffs in 2021. The law would also incorporate demand response and expand the role of renewable energy in the electric matrix. Additionally, and importantly, reforms implemented through PLS 3,975 (which has passed the Brazilian Senate) seek to solve what is known as the Generation Scaling Factor (GSF) issue by performing a structural rebalancing of the Energy Reallocation Mechanism, in which multiple (typically hydroelectric) facilities share the responsibility for their contracted generation. When 
all facilities collectively cannot meet the contracted amount, each facility is allocated a GSF (on a monthly basis), which obligates it to purchase a certain amount of energy on the spot market in order to make up the difference. This system has resulted in many financial challenges and lawsuits (Global Legal Insights 2020) and would be addressed through structural changes established by the new legislation.

The Brazilian government has been seeking to privatize the national electric company, Eletrobras, for several years with the goal of making the company operate more efficiently. A bill sent to the Brazilian Congress at the end of 2019 established a set of guidelines for the privatization: the sale of the company must maximize financial return; must meet the highest corporate governance requirements of a capital market; must limit the voting power of the shareholders with the largest holdings; and, ultimately, must reduce electric-sector charges for end users (Nascimento 2020). Additionally, three distribution companies (Companhia Energetica de Brasilia, Companhia Estadual de Distribuição de Energia Elétrica, and Companhia de Eletricidade do Amapá) are seeking privatization. The Eletrobras privatization process was delayed due to COVID-19 (see later section on COVID-19 Effects).

\section{The EU-Mercosur Agreement}

The European Union (EU) and Mercosur states (Argentina, Brazil, Paraguay, and Uruguay) have been working on a free-trade agreement, reaching an agreement in principle in June 2019, because the EU is the largest foreign investor and trade partner (European Union 2020). The goals of the agreement include increasing bilateral trade, developing a more stable investment environment, and protecting the environment and workers' rights. Concerns over environmental problems and management in Brazil have caused challenges to the agreement's progress (Stuenkel 2020; Canineu and Guajajara 2020). If the agreement is ratified, it could provide competition for U.S. companies and investors, but it might also bolster the U.S. and European positions in Brazil and Argentina relative to China. ${ }^{34}$

\section{COVID-19 Effects}

Due to shutdowns and reduced economic activity, as of June 2020, electricity demand was expected to fall $5 \%$ through midyear, and the national operator expects demand to remain depressed (BNAmericas 2020a). Distributors in Brazil were hit particularly hard. Due to customers' inability to pay their bills, the distribution companies expected the impacts on liquidity to exceed USD \$3 billion; this will cause problems for distributors as well as generation and transmission owners. At least three of the big distributors (Equatorial Energia SA, CPFL Energia SA, and Enel SpA) have been seriously affected. Judicial rulings prevented electrical services from being cut and the government worked to renegotiate contracts with distributors, including obtaining load revisions in order to improve system planning.

A 'COVID account' established by the Brazilian government helped distributors dealing with energy oversupply and nonpayment of bills. In late June 2020, Brazil's energy sector regulator, ANEEL, approved a 16 billion reais (USD \$3.1 billion) bailout package, which had been requested by Brazil's largest distribution companies (including Italy's Enel SpA and CPFL Energia SA, owned by the State Grid Corporation of China, as well as local firms Energisa SA

\footnotetext{
${ }^{34}$ For more information, see analysis in https://www.ft.com/content/a04c186b-ab3f-4df3-99fb-638b5aa1ce50
} 
and Equatorial Energia SA) to help cover the effects of a drop in demand and higher consumer delinquency rates because of the coronavirus pandemic. This bailout will help reduce the risk of distribution companies failing to pay for their contracts and other effects that could cascade through the electrical system's financial structures.

Despite the emergency measures, demand reduction could cause consolidation among smaller companies in the market, with those best able to adapt to digitalization and tap efficiencies better weathering the crisis (Tissot and Martin 2020).

There is concern that the pandemic will cause another recession in Brazil (World Bank 2020), particularly because the country was still recovering from the 2015-2016 recession at the time COVID-19 appeared. Fiscal buffers established to respond to the earlier recession had not had time to create enough fiscal space to absorb current shocks due to reduction of economic activity and reduced oil revenue. Estimates for growth or contraction have changed continuously as the COVID-19 situation changes in each country and worldwide; nevertheless, some measure of economic contraction is likely and a significant longer-term reduction in electricity demand is predicted by Brazilian power system planners as a result. ${ }^{35}$

Like much of the world, the people most affected by the pandemic's fallout are likely to be those already in poverty, and the companies most likely to be economically affected are smaller firms. Local and state governments are also financially vulnerable, although federal financial support will help close their funding gaps. The financial sector, which was strong before the crisis began, should be able to withstand the economic shocks unless the crisis is prolonged; nevertheless, banks may be more reluctant to lend during this crisis, which could reduce liquidity and challenge firms' and households' ability to endure. The fiscal response as of July 2020 was estimated by the World Bank at about $8.6 \%$ of Brazil's gross domestic product (World Bank 2020). While Brazil's international monetary policy framework prior to the crisis offered significant resilience, the need for spending, coupled with the recession and drop in revenues, is expected to increase public debt, exacerbating currency devaluation. Combined with federally mandated reductions in interest rates and perceptions about general vulnerability to COVID-19 effects across the economy, this could significantly erode investor confidence.

The rippling financial effects of reduced demand require the federal government to identify financial support mechanisms for utility companies, such as credit operation with a pool of banks, in order to avoid cross default in the sector. This may provide an opportunity to review customer tariffs and simplify the fees, subsidies, incentives, and taxes that currently make up $38 \%$ of the typical customer bill (Nascimento 2020). This could make the entire sector more competitive as well as streamline and provide transparency for the use of incentives. There was a driver for this already (through Decree 9,642 in 2018), but because a broad default would cascade through the industry and cause many other fiscal problems, there is a much stronger incentive to act.

\footnotetext{
35 See Brazil Ministerio de Minas e Energia, Empresa de Pesquisa Energética, PDE 2030 report: “Avaliação do Suprimento de Potência no Sistema Elétrico e impactos da Covid-19," August 2020, which predicts a 10-GW lesser demand in 2029 than the projections that were made in the PDE 2029 report developed in 2019.
} 


\section{C.3 Renewable Energy Policy in Argentina}

Argentina's 2015 Law 27,191 "Legal Regulations on National Promotion for the Use of Sources of Renewable Energy_Electric Power Generation," amending the 2006 Law 26,190, set a goal that $20 \%$ of the Argentine generation matrix should be comprised of renewable energy sources by 2025 , including small-scale hydropower plants (up to $50 \mathrm{MW}$ ). These laws established an auction mechanism and a series of tax incentives designed to promote renewable energy project investment. This led to a new wave of electricity generation projects in Argentina.

To implement Law 27,191, the government established an auction system with CAMMESA as an offtaker, known as RenovAr, and designed a term market (Mater) that allows large users to directly contract the supply of clean energy. It also established tax benefits and, with the assistance of the World Bank, established financial risk mitigation mechanisms for renewable projects through a trust fund (Foder).

In the first three rounds of the RenovAr auctions, 20 small hydroelectric projects won approval (see C.4, Recent Developments in Argentina). After the success of these auctions, and the achievements of the Mater, Argentina earned a place among the top new markets for renewable energy. The country moved from $20^{\text {th }}$ place in the 2017 Bloomberg New Energy Finance Global Climatescope ranking - which measures the conditions of investment in clean energy in each country - to $12^{\text {th }}$ place in the 2018 edition, and to $7^{\text {th }}$ place in the 2019 edition. ${ }^{36}$ In 2019 , renewable generation represented 5\% of market demand, double the amount in 2018. In June 2020 , renewables boosted production by 55\% year-over-year compared with 2019 , meeting a total of $8 \%$ of demand (Djunisic 2020). ${ }^{37}$ However, the country faces limitations associated with transmission capacity, which have prevented the development of many renewable energy projects.

\section{C.4 Recent Developments in Argentina}

Argentina's new government, which came into office in December 2019, came in facing two leading energy issues: expanding the capacity of electricity transmission and natural gas transport. The extension of the electricity transmission network is essential not only to continue expanding the generation capacity from renewable energy sources, but also to be able to interconnect a significant number of renewable projects from both the RenovAr and Mater programs and to reach demand centers such as Buenos Aires.

In late 2019, under the new administration, the Argentinean Congress approved a bundle bill called the "Economic Solidarity and Production Increase Law." The bill aimed to increase tax collection and take other austerity measures in order to prevent Argentina from going into default, while still protecting poorer citizens through spending on social programs. Specific to the electric power sector, the new bill froze electricity rates for 6 months and aimed to maintain energy costs in Argentine pesos instead of U.S. dollars.

According to analysts with BNAmericas (BNAmericas 2020a), the new Argentinian presidential administration initially appeared to be less interested in implementing the RenovAr auction

\footnotetext{
${ }^{36}$ Tool available at: http://global-climatescope.org/results

${ }^{37} \mathrm{https}$ ://renewablesnow.com/news/argentinas-renewables-boost-production-by-552-yy-in-june-706952/
} 
mechanisms and has demonstrated more interest in large-scale projects with a high level of government involvement in partnership with Argentine provinces, such as large hydroelectric, nuclear, and natural gas generation projects, as well as transmission infrastructure upgrades. However, in late 2020, the Argentine energy secretariat began the process of developing a new auction under or similar to RenovAr that would target smaller wind and biomass projects that could connect to medium- and low-voltage transmission lines (BNAmericas 2020b).

\section{COVID-19}

The COVID-19 crisis and shutdowns to protect public health significantly reduced electricity demand (more than 10\% in April and anticipated to be nearly 5\% for the balance of the year [Fitch Solutions 2020]) and economic activity overall. The government issued a decree preventing the power company from cutting off users' power for lack of payment, but consequently needed to subsidize the wholesale market payment manager CAMMESA in order to keep it solvent. CAMMESA pays its PPA contractors in U.S. dollars but receives revenue in Argentine pesos, meaning that extreme inflation requires even higher government subsidies.

The economic challenges facing Argentina continue to make news. By mid-2020, reports suggested that Argentina's economy would shrink $12 \%$ in 2020, and the poverty rate, already around $40 \%$ in 2019 , would increase, with $58.6 \%$ of children living in poverty by year's end (Soria 2020). In late July 2020, Bloomberg reported that a number of multinational companies were exiting or ceasing operations in Argentina because of economic instability, the enduring recession, government policies surrounding currency exchange, and conflicts with powerful labor unions (Gillespie 2020). Companies were moving manufacturing to other countries, ceasing services (such as airline routes) in Argentina, or canceling investments in expansion plans, even if they were not exiting the country altogether. These circumstances may make international investment in Argentine projects, or collaboration with Argentine companies, higher risk and more challenging to navigate.

Also due to the pandemic and macroeconomic challenges, the projects selected under RenovAr Round 3 have experienced delays in contracting; several companies were unable to meet timesensitive conditions for contracting so deadlines for these contracts were repeatedly extended in 2020 (BNAmericas 2020b).

\section{Debt Negotiations}

Before the COVID-19 crisis, Argentina was already experiencing a very high inflation rate (as much as 50\%) and a shortfall of government revenue to pay down its international debt. Once the pandemic began, the country experienced significant reductions in economic activity and increased inflation. Consequently, the government suffered a shortfall of revenue and defaulted on its international debt payments in May 2020. The Argentine government worked diligently through the subsequent months to negotiate a new arrangement with creditors. A deal was struck in August 2020 with private creditors, but Argentina's president cautioned that the government would still face extreme challenges managing the debt in the face of the pandemic's economic impacts (The Economist 2020). As of publication, the Government of Argentina was negotiating its debt with the International Monetary Fund (IMF). This situation may contribute to other factors influencing investor confidence in the Argentine economy and energy sector. 